\title{
Stable isotopes track the ecological and biogeochemical legacy of mass mangrove forest dieback in the Gulf of Carpentaria, Australia
}

\author{
Yota Harada ${ }^{1}$, Rod M. Connolly ${ }^{1}$, Brian Fry ${ }^{2}$, Damien T. Maher ${ }^{3,4}$, James Z. Sippo ${ }^{3}$, Luke C. Jeffrey ${ }^{3}$, \\ Adam J. Bourke ${ }^{5}$, and Shing Yip Lee ${ }^{6}$ \\ ${ }^{1}$ Australian Rivers Institute - Coast and Estuaries, and School of Environment and Science, Griffith University, \\ Gold Coast, Queensland, Australia \\ ${ }^{2}$ Australian Rivers Institute, Griffith University, Nathan, Queensland, Australia \\ ${ }^{3}$ Southern Cross Geoscience, Southern Cross University, Lismore, New South Wales, Australia \\ ${ }^{4}$ School of Environment, Science and Engineering, Southern Cross University, Lismore, NSW, Australia \\ ${ }^{5}$ College of Engineering, Information Technology and the Environment, Charles Darwin University, \\ Northern Territory, Australia \\ ${ }^{6}$ Simon F.S. Li Marine Science Laboratory, School of Life Sciences, and Earth System Science Programme, \\ The Chinese University of Hong Kong, Shatin, Hong Kong SAR, China
}

Correspondence: Yota Harada (yota.harada@griffithuni.edu.au)

Received: 2 December 2019 - Discussion started: 2 March 2020

Revised: 1 October 2020 - Accepted: 4 October 2020 - Published: 18 November 2020

\begin{abstract}
A combination of elemental analysis, bulk stable isotope analysis (bulk SIA) and compound-specific stable isotope analysis of amino acids (CSIA-AA) was used to assess and monitor carbon $(\mathrm{C})$, nitrogen $(\mathrm{N})$ and sulfur $(\mathrm{S})$ cycling of a mangrove ecosystem that suffered mass dieback of trees in the Gulf of Carpentaria, Australia in 2015-2016, attributed to an extreme drought event. Three field campaigns were conducted 8, 20 and 32 months after the event over a period from 2016 to 2018 to obtain biological time-series data. Invertebrates and associated organic matter including mangroves and sediments from the impacted ecosystem showed enrichment in ${ }^{13} \mathrm{C},{ }^{15} \mathrm{~N}$ and ${ }^{34} \mathrm{~S}$ relative to those from an adjacent unimpacted reference ecosystem, likely indicating lower mangrove carbon fixation, lower nitrogen fixation and lower sulfate reduction in the impacted ecosystem. For example, invertebrates representing the feeding types of grazing, leaf feeding and algae feeding were more ${ }^{13} \mathrm{C}$ enriched at the impacted site, by $1.7 \% \circ-4.1 \%$, and these differences did not change over the period from 2016 to 2018. The CSIA-AA data indicated widespread ${ }^{13} \mathrm{C}$ enrichment across five essential amino acids and all groups sampled (except filter feeders) within the impacted site. The seedling density increased from $0.2 \mathrm{~m}^{-2}$ in 2016 to $7.1 \mathrm{~m}^{-2}$ in 2018 in the impacted forest, suggesting recovery of the vegetation. Recovery of
\end{abstract}

CNS cycling, however, was not evident even after 32 months, suggesting a biogeochemical legacy of the mortality event. Continued monitoring of the post-dieback forest is required to predict the long-term trajectory of ecosystem recovery. This study shows that time-series SIA can track biogeochemical changes over time and evaluate recovery of an impacted ecosystem from an extreme event.

\section{Introduction}

Low-frequency, high-intensity weather events, such as droughts, tropical cyclones, heatwaves and climatic extremes can cause mass mortality of foundation species such as mangroves (Sippo et al., 2018), saltmarshes (Silliman et al., 2005), seagrasses (Thomson et al., 2015), kelps (Wernberg et al., 2016) and corals (Hughes et al., 2017). The frequency and intensity of extreme climatic events are expected to increase due to climate change (Coumou and Rahmstorf, 2012; Stott, 2016). In 2015-2016, an extensive area (> 7000 ha) of mangrove forest along $\sim 1000 \mathrm{~km}$ of coastline in the Gulf of Carpentaria, Australia, experienced severe dieback, an event associated with the climatic extreme of drought (Duke et al., 2017; Sippo et al., 2020a). As mangroves show characteris- 
tics of pioneer species (Tomlinson, 2016), large-scale disturbances have likely played an important role in their evolution. However, the processes, rates and patterns of recovery from disturbances are still largely unknown. In most cases, recovery of mangroves primarily relies on the recruitment of seedlings (Smith et al., 1994; Krauss and Osland, 2019). Disturbances in mangrove forests not only affect recruitment but can also change the cycling of $\mathrm{C}, \mathrm{N}$ and $\mathrm{S}$. Loss of mangrove trees and root structures can change organic matter inputs, sediment oxygenation and degradation of sediment organic matter, with consequences for benthic assemblages (Sweetman et al., 2010; Bernardino et al., 2018; Harada et al., 2019), the coastal carbon cycle (Jeffrey et al., 2019; Sippo et al., 2020b), sediment $\mathrm{C}$ and $\mathrm{N}$ stocks (Adame et al., 2018), microbial assemblages, and associated nutrient processes, e.g. nitrogen fixation and sulfate reduction (Sjöling et al., 2005). Although mangroves can recover from mortality events, the rate of recovery can be slow. For example, a study of mangrove mortality attributed to an oil spill incident shows that full canopy recovery may take over 50 years (Connolly et al., 2020). Full recovery of below-ground $\mathrm{C}$ and $\mathrm{N}$ stocks may take over 40 years after mangrove replantation (Adame et al., 2018).

Stable isotope analysis (SIA) provides biogeochemical process information integrated over time and is useful for environmental assessment and monitoring. As elements such as carbon $(\mathrm{C})$, nitrogen $(\mathrm{N})$ and sulfur $(\mathrm{S})$ circulate in the biosphere, stable isotopic compositions of ${ }^{13} \mathrm{C} /{ }^{12} \mathrm{C},{ }^{15} \mathrm{~N} /{ }^{14} \mathrm{~N}$ and ${ }^{34} \mathrm{~S} /{ }^{32} \mathrm{~S}$ can change in predictable ways due to mixing and fractionation, giving insights into sources and cycling of these elements (Fry, 2006). SIA has been widely used in mangrove ecosystem studies to better understand food web interactions (Bouillon et al., 2008; Larsen et al., 2012; Bui and Lee, 2014; Abrantes et al., 2015); nutrient uptake (McKee et al., 2002); water use (Santini et al., 2015; Hayes et al., 2019); cycling of C (Maher et al., 2013a, 2017; Sasmito et al., 2020), N (Fry and Cormier, 2011) and S (Raven et al. 2019); and greenhouse gas emissions (Maher et al., 2013b). While traditional field methods such as measuring species composition to evaluate the structure and functioning of ecosystems can be time-consuming and expensive, SIA of ecosystem components can evaluate functional aspects of element cycling and food webs in a cost-effective way (Fry, 2006). To quantify food web dynamics, SIA of total organic matter ("bulk") requires determination of the baseline isotope values of the food web, but this is difficult to achieve, particularly for complex detrital food webs. Some of the uncertainties associated with bulk SIA have been clarified by compound-specific isotope analysis of amino acids (CSIAAA). This technique has been increasingly used to assess pathways of energy transfer throughout food webs by distinguishing the effects of baseline isotope values and trophic transfer. Distinct isotopic fractionation between two groups of amino acids occurs with each trophic transfer. In general, non-essential and/or trophic AAs show large isotopic frac- tionation per trophic step, while essential and/or source AAs show little fractionation, reflecting the baseline isotope values of the food web (Ishikawa et al., 2018; Larsen et al., 2013; Ohkouchi et al., 2017).

We investigated changes in $\mathrm{C}, \mathrm{N}$ and $\mathrm{S}$ cycling associated with the Gulf of Carpentaria mangrove forest dieback (Duke et al., 2017), using a combination of traditional ecological survey techniques, bulk SIA and CSIA-AA of carbon. We hypothesised that the mortality of mangrove foundation species has changed the overall circulation of $\mathrm{C}, \mathrm{N}$ and $\mathrm{S}$ elements and that these biogeochemical changes would most likely be reflected in $\delta^{13} \mathrm{C}, \delta^{15} \mathrm{~N}$ and $\delta^{34} \mathrm{~S}$ values of mangrove ecosystem components such as mangrove plants, sediment and associated animals. We also tested the hypothesis that these isotopic compositions changed over time with the recovery of mangrove vegetation. $\delta^{13} \mathrm{C}, \delta^{15} \mathrm{~N}$ and $\delta^{34} \mathrm{~S}$ values were measured for samples including mangroves, sediment and invertebrates collected in a comparative setting of an impacted mangrove forest site and an adjoining unaffected reference forest site in the Gulf of Carpentaria, Australia.

\section{Material and methods}

\subsection{Study site}

The Gulf of Carpentaria in tropical northern Australia is an extensive, shallow coastal gulf. The area mainly consists of low-lying wetlands and is largely inaccessible with little direct human activity. Mangroves are abundant in the area, but the dry climate limits the extent, diversity and height of mangroves in the region (Asbridge et al., 2016). The wide tidal wetlands spread along the shoreline with high intertidal saltpans and saltmarsh covering more area than mangroves. Mangroves are often distributed in the seaward margin, typically as a narrow strip and fronted by extensive, shallow mudflats. The distribution of mangroves in this region is associated with tidal and freshwater inundation, river discharge and regular sediment supply through freshwater input. Increased amounts of rainfall and associated flooding and sea level rise were responsible for recent mangrove extension in this region between 1987 and 2014 (Asbridge et al., 2016). Avicennia marina was the dominant mangrove species at the study site in Karumba, Gulf of Carpentaria (Fig. 1a).

Over 7000 ha of mangroves along $\sim 1000 \mathrm{~km}$ of the Gulf of Carpentaria coastline in Australia experienced mass mortality during the summer in 2015-2016 (Duke et al., 2017), the most extensive mangrove forest dieback ever recorded due to natural causes (Sippo et al., 2018). At the same time, there were coinciding mangrove mass mortality events in Exmouth, Western Australia (Lovelock et al., 2017), and Kakadu National Park, Northern Territory (Asbridge et al., 2019). The climate in the Gulf region is wet-dry tropical with mean annual precipitation ranging from approximately 600 to $900 \mathrm{~mm}$. Dry conditions prevail for 6 to 8 months, 

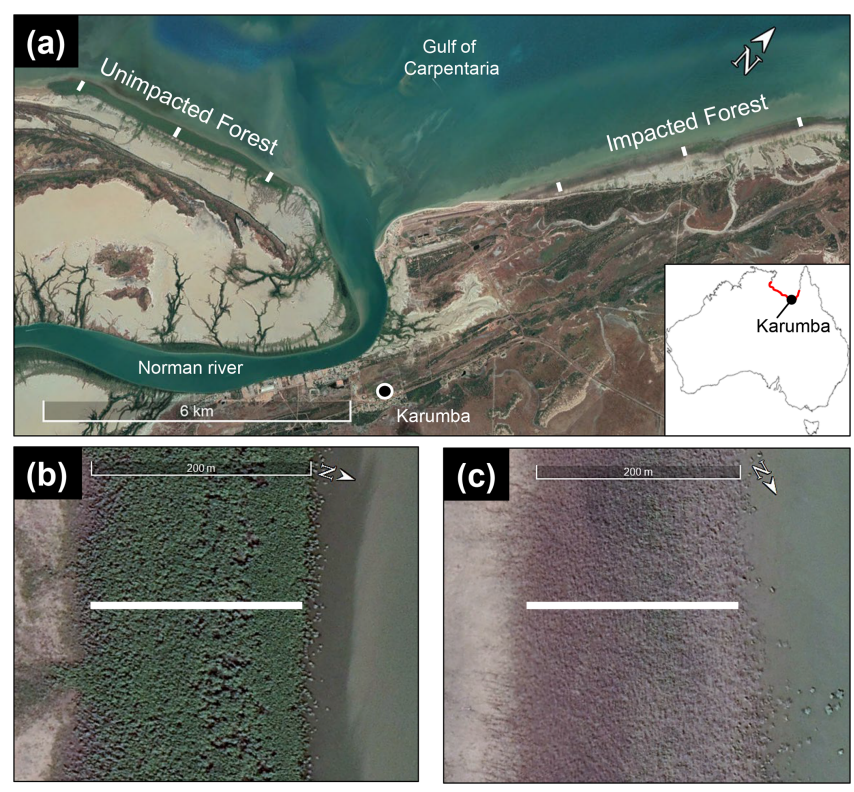

Figure 1. The study location at Karumba in the Gulf of Carpentaria, Queensland, Australia (-17.435572 ${ }^{\circ} \mathrm{S}, 140.844766^{\circ} \mathrm{E}$; image provided by (CGoogle Earth). (a) Three sampling transects within the unimpacted reference site and three within the impacted site (shown as a white line). (b, c) Representative transects from the unimpacted (b) and impacted (c) sites. Each transect was approximately $200 \mathrm{~m}$. Samples were collected along each transect from higher to lower intertidal zones. Red indicated mass dieback region.

and most rainfall occurs between December and March $(\mathrm{Bu}-$ reau of Meteorology; see http://www.bom.gov.au, last access: November 2019). The dieback coincided with a weak monsoon (low rainfall), combined with a high vapour pressure deficit and El Niño-Southern Oscillation-induced low sea levels (Duke et al., 2017; Lovelock et al., 2017; Harris et al., 2017). The drought conditions most likely caused accumulative hydric, thermal and radiant stresses (Duke et al., 2017). In addition to low water availability, iron (Fe) toxicity due to a rapid mobilisation of sedimentary $\mathrm{Fe}$ and regional variability in groundwater flows may have also played a role in the dieback (Sippo et al., 2020a). The event led to the widespread death of mangrove trees in the region, providing an unfortunate yet unique opportunity to test tree mortality effects on the biogeochemical and ecological functioning of mangroves and capture recovery patterns.

Three field campaigns were conducted in August 2016 (8 months after the event), August 2017 (20 months after the event) and August 2018 (32 months after the event) in the winter dry seasons in Karumba. Some local factors (e.g. river influence and localised groundwater flow paths) may have kept some mangroves from dying back in the region. A forest that had suffered dieback (impacted) on the east side of the Norman River outlet and an adjoining unaffected forest (unimpacted) on the west side provided the setting for comparisons. In order to assess differences between the two forests (impacted vs. unimpacted), as well as to capture trends from across the intertidal zone and to ensure that the physical-oceanographic conditions between the two forests were as similar as possible, three sampling transects ( 2 to $2.5 \mathrm{~km}$ apart) were set for each forest, with the length of each transect being approximately $200 \mathrm{~m}$ (Fig. 1b, c). Each transect consists of six sampling plots (approx. $40 \mathrm{~m}$ apart), namely forest edge (landward), high, mid, low, forest edge (seaward) and mudflat (Table 1). Samples from each plot were pooled for analysis. Due to logistical constraints and the presence of saltwater crocodiles, fieldwork was restricted to daytime, low tide and dry seasons.

\subsection{Samples}

Since our focus was to measure the recovery of mangrove vegetation and food webs, we monitored mangrove saplings and seedlings and stable isotopes of invertebrates during the period from 2016 to 2018. Mangrove and sediment samples were also collected, but they are limited to 2018 (Table 1). Some of the SIA samples including invertebrates, mangrove and sediment collected in 2017 were used to measure the initial dieback reported in Harada et al. (2019). During each field campaign, four common mangrove macroinvertebrate groups with different feeding modes were collected from each forest including a leaf-eating crab (Parasesarma moluccensis and/or Episesarma sp.), an algae-eating (deposit-feeding) crab (Tubuca signata), a grazer gastropod (Telescopium telescopium) and a filter-feeding bivalve (Saccostrea sp., an oyster). For each feeding group, three to five individuals at each of the sampling transects $(n=3)$ within the forest were collected and muscle tissues were pooled for SIA. In 2018, fully developed green leaves of A. marina were collected from about 1 to $1.5 \mathrm{~m}$ height, from three to five individual trees (one to three leaves per tree) at each sampling plot, stored in plastic containers and then composited. In the impacted site, leaves were collected from regrowth of trees that had survived. Leaf samples were washed thoroughly and rinsed with distilled water, and the main vein was removed. Additionally, wood samples ( $n=2,5$ to $25 \mathrm{~cm}$ diameter) were collected using a hand saw from stems at chest height from the mid intertidal zone of each forest. Dead trees were sampled at the impacted site. Two to three bulk SIA measurements were made from the sapwood (2 to $3 \mathrm{~cm}$ deep) of each sample and measurements were averaged. Wood samples were generally very low in S and not sufficient for $\delta^{34} \mathrm{~S}$ analysis.

In 2018, surface $(<0.5 \mathrm{~cm})$ sediments that represent the recent deposition and microphytobenthos (MPB) were collected along each transect. Additionally, subsurface ( 0.5 to $20 \mathrm{~cm})$ sediment samples $(n=6)$ that represent long-term averages were collected at the mid intertidal zone of each forest using a core sampler $(5 \mathrm{~cm}$ in diameter and $20 \mathrm{~cm}$ deep). For $\delta^{13} \mathrm{C}$ measurements, the sediment samples were acidified with $1 \mathrm{M} \mathrm{HCl}$ to remove the inorganic fraction. MPB sam- 
Table 1. Spatial and temporal details of the sampling design $(x=$ sampled $)$.

\begin{tabular}{|c|c|c|c|c|c|c|c|c|c|}
\hline & \multicolumn{6}{|c|}{ Sampling plots along each transect } & \multicolumn{3}{|c|}{ Year } \\
\hline & $\begin{array}{c}\text { Forest } \\
\text { edge, } \\
\text { landward }\end{array}$ & High & Mid & Low & $\begin{array}{c}\text { Forest } \\
\text { edge, } \\
\text { seaward }\end{array}$ & Mudflat & $\begin{array}{c}2016, \\
8 \text { months } \\
\text { after } \\
\text { dieback }\end{array}$ & $\begin{array}{c}2017, \\
20 \text { months } \\
\text { after } \\
\text { dieback }\end{array}$ & $\begin{array}{c}2018, \\
32 \text { months } \\
\text { after } \\
\text { dieback }\end{array}$ \\
\hline Mangrove seedling count & & & $x$ & & & & $x$ & $x$ & $x$ \\
\hline Bulk SIA invertebrates* & & $x$ & $x$ & $x$ & & & $x$ & $x$ & $x$ \\
\hline CSIA invertebrates* & & $x$ & $x$ & $x$ & & & & $x$ & \\
\hline Bulk SIA mangrove leaves & $x$ & $x$ & $x$ & $x$ & $x$ & & & & $\times$ \\
\hline Bulk SIA mangrove wood & & & $x$ & & & & & & $\times$ \\
\hline Bulk SIA surface sediment & $x$ & $\times$ & $x$ & $x$ & $x$ & $x$ & & & $\times$ \\
\hline Bulk SIA subsurface sediment & & & $x$ & & & & & & $x$ \\
\hline
\end{tabular}

* For invertebrate SIA, to gain sufficient sampling size, high, mid and low plots were pooled for analysis.

ples $(n=6)$ were separated from surface sediment collected at each forest. The separation was achieved through density gradient centrifugation in Ludox colloidal silica (Sigma) as described in Bui and Lee (2014). The MPB extraction was followed by microscopic examination to confirm that samples mostly contained green cells (i.e. diatoms and filamentous cyanobacteria). Additionally, surface sediment samples were collected offshore (approx. $1 \mathrm{~km}$ ) using a grab sampler and from the adjacent saltpan (approx. $200 \mathrm{~m}$ inland from the forest). Offshore water samples $(n=3)$ were also collected and then filtered through glass fibre filters (diameter $44 \mathrm{~mm}$, pore size $0.7 \mu \mathrm{m}$, Whatman $\mathrm{GF} / \mathrm{F}$ ) to obtain particulate organic matter (POM), material such as phytoplankton that is transported to the mangrove.

To estimate mangrove seedling and sapling densities (individuals per square metre) from each forest and their changes over time, seedlings and saplings were counted with a $50 \mathrm{~cm} \times 50 \mathrm{~cm}$ quadrat at the mid intertidal zone. A photo was taken of each quadrat (for 2016, $n=124$ for the unimpacted forest and $n=143$ for the impacted forest; for 2017, $n=161$ and $n=175$; and for 2018, $n=80$ and $n=117$, respectively), and then counts of seedlings and samplings were made in the laboratory. The seedlings and samplings were mostly A. marina but also include some Aegiceras corniculatum.

\subsection{Stable isotope analysis}

All invertebrate, leaf, sediment and filter samples were stored separately in sealed plastic containers at $-20^{\circ} \mathrm{C}$ until analysis, then dried at $60^{\circ} \mathrm{C}$, powdered, homogenised and put in tin capsules for SIA. $\delta^{13} \mathrm{C}, \delta^{15} \mathrm{~N}$ and $\delta^{34} \mathrm{~S}$ measurements were carried out on an elemental analyser (Europa EA-GSL, Sercon) coupled to an isotope ratio mass spectrometer (Hydra 20-22, Sercon) at Griffith University, Brisbane, Australia. Isotope values are reported relative to Vienna Pee Dee Belemnite (PDB), atmospheric $\mathrm{N}_{2}$ (AIR) and Vienna Canyon
Diablo Troilite (VCDT) for C, N and S, respectively. Harada et al. (2019) reported $\delta^{13} \mathrm{C}$ and $\delta^{15} \mathrm{~N}$ values for some of the samples collected in 2017 from the same study location.

The samples collected in 2017 showed substantial differences in $\delta^{13} \mathrm{C}$ values between the two forests (Harada et al., 2019), suggesting that they are representative of the dieback impact. The 2017 samples from each forest including the mangrove leaf $(n=2)$, MPB $(n=1)$, algae feeder $(n=3)$, leaf feeder $(n=2$ to 3$)$, grazer $(n=3)$, and filter feeder $(n=2)$ were further measured for carbon isotopic composition of individual amino acids $\left(\delta^{13} \mathrm{C}_{\mathrm{AA}}\right)$. A total of $8 \mathrm{mg}$ (for animal tissues) or $30 \mathrm{mg}$ (for plant tissues) of sample materials were transferred to borosilicate vials with heat- and acidresistant caps. They were then flushed with $\mathrm{N}_{2}$ gas, sealed and hydrolysed in $0.5 \mathrm{~mL}$ (animal tissues) or $2 \mathrm{~mL}$ (plant tissues) of $6 \mathrm{M} \mathrm{HCl}$ at $150^{\circ} \mathrm{C}$ for $70 \mathrm{~min}$, then dried in a heating block at $60^{\circ} \mathrm{C}$ under a stream of $\mathrm{N}_{2}$ gas. The dried samples were derivatised by methoxycarbonylation as described by Walsh et al. (2014). Amino acid derivatives were separated by a Trace GC Ultra gas chromatograph (GC) (Thermo Scientific) using a DB-23 column (Agilent, $30 \mathrm{~m} \times 0.25 \mathrm{~mm}$, $0.25 \mu \mathrm{m}$ film) at the stable isotope facility at the University of California (Davis, CA, USA). The GC was interfaced with a Delta V Plus isotope ratio mass spectrometer via a GC IsoLink (Thermo Scientific). L-Norleucine was used as an internal standard and to calculate provisional values. Pure AA mixtures with calibrated $\delta^{13} \mathrm{C}$ were co-measured. One mixture was used for final calibration and others were for the scale normalisation standard and the primary quality assurance standard (unused in corrections). Two working standards were co-measured as secondary quality assurance materials. Exogenous carbon was accounted for using the method detailed by Docherty et al. (2001). Following these processes, $\delta^{13} \mathrm{C}$ values were determined for $10 \mathrm{AAs}$ (Gly, glycine; Asx, aspartic acid/asparagine; Pro, proline; Glx, glutamic acid/glutamine; Ala, alanine; Lys, lysine; Ile, isoleucine; Leu, leucine; Phe, phenylalanine; and Val, va- 
line). Met, methionine; His, histidine; and Hyp, hydroxyproline were at or below the limit of quantitation (LOQ) for some samples. Since we were interested in $\delta^{13} \mathrm{C}$ values of essential amino acids $\left(\delta^{13} \mathrm{C}_{\mathrm{EAA}}\right), \delta^{13} \mathrm{C}$ values of Lys, Ile, Leu, Phe and Val were reported in the study.

\subsection{Data analysis}

All statistical analyses were undertaken in $\mathrm{R}$ version 3.4.3 with RStudio interface version 1.1.414. Differences among group means were explored with ANOVA, but for the count data, i.e. seedling and sampling density, a generalised linear model (GLM) with Poisson distribution was used. Before performing ANOVA, the assumptions of homogeneity of variance and normality were tested using Levene and Shapiro-Wilk tests, respectively. Two-way ANOVA was used to test the effects of time (year) and forest type (unimpacted and impacted) on stable isotope values of invertebrates. To explore $\delta^{13} \mathrm{C}$ patterns among five EAAs, $\delta^{13} \mathrm{C}_{\mathrm{EAA}}$ values were normalised to the respective sample means following the procedure of Larsen et al. (2009) as follows:

$\operatorname{Norm}\left(\delta_{\mathrm{EAA}}\right)=\delta_{\mathrm{EAA}}-\mu$,

where $\mu$ represents the mean value of all five EAAs (Ile, Leu, Lys, Phe and Val) in the sample. PERMANOVA was performed to test if the pattern of $\delta^{13} \mathrm{C}$ among five EAAs of samples differ between the forests. In this analysis, the normalised $\delta^{13} \mathrm{C}_{\mathrm{EAA}}$ dataset was used and the Euclidean distance was used as distance metric. Permutation test of the multivariate homogeneity of dispersions was performed to check whether dispersions around the centroids are similar between the two forests. All statistical tests used a significance criterion of $\alpha=0.05$.

\section{Results}

\subsection{Mangroves}

In 2016, at the impacted site, mangrove seedling and sapling populations were lower than at the unimpacted site (GLM df $=1$, estimate $3.75, p<0.001$ ) but significantly increased throughout the period from 2016 to 2018 (GLM df $=2$, estimate $0.01, p<0.001$; Fig. 2). $\mathrm{C}, \mathrm{N}$ and $\mathrm{S}$ elemental compositions (\%) of A. marina did not differ significantly between the two sites, but the isotopic compositions varied significantly (Table 2). The $\delta^{13} \mathrm{C}$ values (mean $\pm \mathrm{SD}$ ) of green leaves harvested from $A$. marina trees were significantly higher (i.e. more ${ }^{13} \mathrm{C}$ enriched) in the impacted site $(-25.8 \pm 1.0 \%$ o than the unimpacted site $\left(-28.4 \pm 1.5 \%\right.$; ANOVA $F_{1,28}=32.9$, $p<0.001$; Fig. 3a, Table 2). The $\delta^{15} \mathrm{~N}$ values varied more in the impacted site (ranged from $-0.9 \%$ o to $6.7 \%$ ) than in the unimpacted site (ranged from $2.9 \%$ to $6.2 \%$; Fig. 3a). The $\delta^{34} \mathrm{~S}$ values were generally higher in the impacted site $(13.5 \pm 5.4 \%$, range $7.7 \%$ to $23.3 \%$ ) than the unimpacted
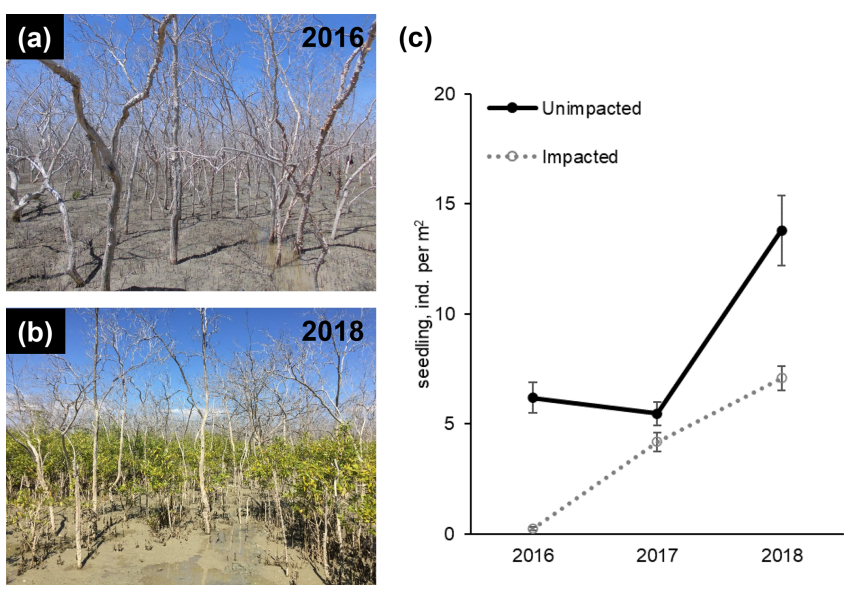

Figure 2. Recovery of mangrove vegetation at the impacted site during a 2-year period from 2016 to 2018 (a and b; approx. 8 and 32 months, respectively, after the dieback event). Seedling and sampling densities of mangrove species (mostly, A. marina) significantly increased in the impacted site (c; Table $\mathrm{S} 1)$.

site $\left(12.6 \pm 5.6 \%\right.$ o, range $5.0 \%$ to $21.9 \%$ ). Leaf $\delta^{34} \mathrm{~S}$ values became more ${ }^{34} \mathrm{~S}$ depleted from higher to lower intertidal zones in the impacted site (ANOVA $F_{4,10}=5.56, p=$ 0.013 ; Fig. 3b). This pattern was weaker in the unimpacted site, but leaf $\delta^{34} \mathrm{~S}$ values significantly varied across intertidal zones (ANOVA $F_{4,10}=6.48, p=0.007$; Fig. 3b). Leaf $\delta^{13} \mathrm{C}$ and $\delta^{15} \mathrm{~N}$ values did not display such patterns along the intertidal zones (Table S2 in the Supplement). Leaf C, N and S (\%) did not show any clear trends among the two forests and along transects. Yellow leaves generally had a higher $\mathrm{S}$ content $(\sim 1.2 \%)$ than green leaves $(0.5 \%$ to $0.7 \%)$ (Table 2$)$. Wood samples generally had very low $\mathrm{N}$ and $\mathrm{S}$ contents, significantly lower than the leaves.

\subsection{Sediment}

For the surface $(<0.5 \mathrm{~cm})$ sediment collected in 2018, TOC (\%) differed significantly between the two forests, with the values (mean \pm SD) of $2.02 \pm 1.16 \%$ for the unimpacted site and $1.06 \pm 0.37 \%$ for the impacted site (ANOVA $\left.F_{1,28}=12.75, p=0.001\right)$, suggesting that the surface sediment from the impacted site contains $\sim 48 \%$ lower TOC relative to that of the unimpacted site (Table 3 ). The surface sediment TN (\%) was also significantly lower for the impacted site $(0.09 \pm 0.03)$ than the unimpacted site $\left(0.15 \pm 0.06 \%\right.$; ANOVA $\left.F_{1,28}=9.32, p=0.005\right)$. TOC of mudflat $(<0.5 \mathrm{~cm})$ sediment collected adjacent to the two forests also differed significantly, with those of the impacted site being lower $(0.58 \pm 0.18 \%)$ than the unimpacted site $\left(1.02 \pm 0.08 \%\right.$; ANOVA $\left.F_{1,4}=14.54, p=0.019\right)$. The TN $(\%)$ of mudflat $(<0.5 \mathrm{~cm})$ sediment was also significantly lower for the impacted site (ANOVA $F_{1,4}=9.81$, $p=0.035)$. The TOC (\%) of the $0.5-20 \mathrm{~cm}$ sediment did not differ significantly between the two sites, with the val- 
Table 2. Elemental and isotopic compositions of the mangrove A. marina (mean, SD) in 2018, 32 months after the dieback.

\begin{tabular}{llrrrrrrr}
\hline Tissue type & Forest & $\% \mathrm{C}$ & $\% \mathrm{~N}$ & $\% \mathrm{~S}$ & $\delta^{13} \mathrm{C}, \% \circ$ & $\delta^{15} \mathrm{~N}, \% \circ$ & $\delta^{34} \mathrm{~S}, \% 0$ & $n$ \\
\hline \multirow{2}{*}{ Green leaf } & Unimpacted & $39.3 \pm 1.7$ & $1.75 \pm 0.37$ & $0.54 \pm 0.23$ & $-28.4 \pm 1.5$ & $4.4 \pm 0.8$ & $12.6 \pm 5.6$ & 15 \\
& Impacted & $40.0 \pm 1.6$ & $1.82 \pm 0.45$ & $0.73 \pm 0.14$ & $-25.8 \pm 1.0$ & $4.3 \pm 1.9$ & $13.5 \pm 5.4$ & 15 \\
\hline \multirow{2}{*}{ Yellow leaf } & Unimpacted & $41.6 \pm 2.2$ & $0.67 \pm 0.23$ & $1.18 \pm 0.47$ & $-26.4 \pm 1.3$ & $6.5 \pm 1.1$ & $14.6 \pm 7.7$ & 3 \\
& Impacted & $41.9 \pm 1.0$ & $0.52 \pm 0.05$ & $1.18 \pm 0.38$ & $-26.2 \pm 0.6$ & $7.4 \pm 0.2$ & $12.5 \pm 2.8$ & 3 \\
\hline \multirow{2}{*}{ Wood } & Unimpacted & $42.6 \pm 3.0$ & $0.38 \pm 0.27$ & $0.04 \pm 0.01$ & $-24.8 \pm 1.8$ & $6.1 \pm 2.0$ & - & 2 \\
& Impacted & $39.9 \pm 5.7$ & $0.40 \pm 0.16$ & $0.31 \pm 0.37$ & $-24.9 \pm 1.0$ & $4.7 \pm 1.0$ & - & 2 \\
\hline
\end{tabular}

(a)
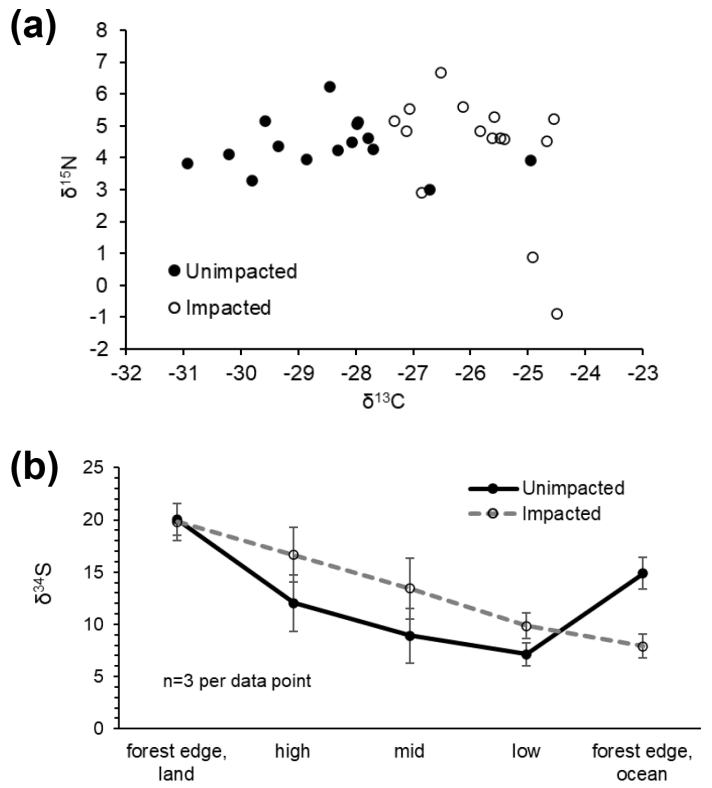

Figure 3. CNS isotopic compositions of green leaves of A. marina from the unimpacted and impacted sites. All samples were collected in 2018, 32 months after the dieback. (a) Leaf $\delta^{13} \mathrm{C}$ and $\delta^{15} \mathrm{~N}$ values. (b) Leaf $\delta^{34} \mathrm{~S}$ values across the intertidal zones. Error values are SE.

ues of $1.83 \pm 0.73 \%$ for the unimpacted and $1.29 \pm 0.55 \%$ for the impacted site (ANOVA $F_{1,10}=2.07, p=0.181$ ). The TN $(\%)$ of the $0.5-20 \mathrm{~cm}$ sediment also did not differ significantly between the two sites, with the values of $0.09 \pm 0.03 \%$ for the unimpacted and $0.12 \pm 0.04 \%$ for the impacted site (ANOVA $F_{1,10}=3.02, p=0.113$ ). Despite the substantial variation in TOC and $\mathrm{TN}$, the $\mathrm{C} / \mathrm{N}$ ratio did not differ significantly between the two sites (ANOVA $p>0.05)$.

The $\delta^{13} \mathrm{C}$ values of surface sediment differed significantly between the two sites, with those from the impacted site showing higher values $(-21.8 \pm 1.0 \%$ ) than those from the unimpacted site $\left(-24.3 \pm 1.2 \%\right.$; ANOVA $F_{1,28}=22.48$, $p<0.001)$. This pattern was consistent across the intertidal zones, with $\delta^{13} \mathrm{C}$ values from the impacted site becoming similar to those from the adjacent mudflat (Fig. 4; Table S3).
However, those of the 0.5 to $20 \mathrm{~cm}$ sediment did not differ significantly, with the values of $-24.4 \pm 0.5 \%$ for the impacted site and $-25.2 \pm 0.9 \%$ o for the unimpacted site (ANOVA $F_{1,10}=3.92, p=0.076$ ). Surface sediment collected in the adjacent mudflat did not display a significant difference in $\delta^{13} \mathrm{C}$ values between the two sites, with the values of $-21.2 \pm 0.9 \%$ o for those collected adjacent to the unimpacted forest and $-21.8 \pm 0.8 \%$ o for those collected adjacent to the impacted site (ANOVA $F_{1,4}=0.64, p=0.47$ ). The $\delta^{13} \mathrm{C}$ value of the surface sediment $(-21.8 \pm 1.0 \%$ o in the impacted forest was similar to the value of those collected in the mudflat $(-21.2 \pm 0.9 \%$ ), which were also similar to those collected from offshore $(-21.5 \pm 1.1 \%$ ). Those $\delta^{13} \mathrm{C}$ values also matched with the $\delta^{13} \mathrm{C}$ value of POM collected offshore $(-21.5 \pm 1.5 \%$ ). Surface sediment collected from adjacent unvegetated saltpan areas also showed similar values (Table 3). MPB extracted from the surface sediment showed significantly different $\delta^{13} \mathrm{C}$ values between the impacted site $(-21.5 \pm 1.3 \%$ ) and unimpacted site $\left(-25.2 \pm 1.0 \%\right.$; ANOVA $\left.F_{1,10}=28.53, p<0.001\right)$.

\subsection{Fauna}

CNS isotopic compositions of mangrove macroinvertebrates representing algae feeder, grazers and leaf feeders from the impacted site were more enriched in ${ }^{13} \mathrm{C},{ }^{15} \mathrm{~N}$ and ${ }^{34} \mathrm{~S}$ than their counterparts from the unimpacted forest throughout the period between 2016 and 2018 (Fig. 5). However, the filterfeeding oyster that relies on water column organic matter showed relatively less difference between the two forests (Fig. 5). Overall, $\delta^{13} \mathrm{C}$ values of the four feeding groups range from $-23 \%$ to $-15 \%$ for the unimpacted site and $-20 \%$ o to $-14 \%$ for the impacted site. The $\delta^{15} \mathrm{~N}$ values ranged from $5.5 \%$ o to $9.1 \%$ for the unimpacted site, with the fauna in the impacted site having a slightly higher range of $5.6 \%$ to $9.5 \%$. The $\delta^{34} \mathrm{~S}$ values ranged from $8.2 \%$ to $16 \%$ for the unimpacted site and $13.4 \%$ to $21.7 \%$ for the impacted site. The $\delta^{13} \mathrm{C}, \delta^{15} \mathrm{~N}$ and $\delta^{34} \mathrm{~S}$ values of the algae feeder and the grazer significantly differed between the two forests (ANOVA $p<0.05$ ). The $\delta^{13} \mathrm{C}$ and $\delta^{34} \mathrm{~S}$ values of the leaf feeder significantly differed between the two forests (ANOVA $p<0.05$ ), but the $\delta^{15} \mathrm{~N}$ values were not significantly different (ANOVA $F_{1,13}=1.72, p=0.212$ ). The 
Table 3. Elemental and isotopic compositions of sediment in 2018, 32 months after the dieback (mean, SD).

\begin{tabular}{|c|c|c|c|c|c|c|c|}
\hline & Forest/site & $\% \mathrm{TOC}$ & $\% \mathrm{TN}$ & $\mathrm{C}: \mathrm{N}$ & $\delta^{13} \mathrm{C}, \%$ & $\delta^{15} \mathrm{~N}, \% \circ$ & $n$ \\
\hline \multirow{2}{*}{$\begin{array}{l}\text { Mangrove forest, } \\
0 \text { to } 0.5 \mathrm{~cm}\end{array}$} & Unimpacted & $2.02 \pm 1.16$ & $0.15 \pm 0.06$ & $13.48 \pm 2.49$ & $-24.3 \pm 1.2$ & $2.0 \pm 0.5^{*}$ & 15 \\
\hline & Impacted & $1.06 \pm 0.37$ & $0.09 \pm 0.03$ & $11.67 \pm 2.58$ & $-21.8 \pm 1.0$ & $2.8 \pm 0.6^{*}$ & 15 \\
\hline \multirow{2}{*}{$\begin{array}{l}\text { Mangrove forest, } \\
0.5 \text { to } 20 \mathrm{~cm}\end{array}$} & Unimpacted & $1.83 \pm 0.73$ & $0.12 \pm 0.04$ & $15.12 \pm 1.79$ & $-25.2 \pm 0.9$ & $1.7 \pm 0.5^{*}$ & 6 \\
\hline & Impacted & $1.29 \pm 0.55$ & $0.09 \pm 0.03$ & $14.71 \pm 2.81$ & $-24.4 \pm 0.5$ & $1.7 \pm 0.3^{*}$ & 6 \\
\hline \multirow{2}{*}{$\begin{array}{l}\text { Mudflat, } \\
0 \text { to } 0.5 \mathrm{~cm}\end{array}$} & Unimpacted & $1.02 \pm 0.08$ & $0.11 \pm 0.01$ & $9.07 \pm 0.91$ & $-21.8 \pm 0.8$ & - & 3 \\
\hline & Impacted & $0.58 \pm 0.18$ & $0.07 \pm 0.02$ & $8.78 \pm 0.93$ & $-21.2 \pm 0.9$ & - & 3 \\
\hline \multirow{2}{*}{$\begin{array}{l}\text { Saltpan, } \\
0 \text { to } 0.5 \mathrm{~cm}\end{array}$} & Unimpacted & $1.87 \pm 2.03$ & $0.19 \pm 0.24$ & $11.44 \pm 3.05$ & $-18.9 \pm 1.7$ & - & 4 \\
\hline & Impacted & $0.83 \pm 0.07$ & $0.07 \pm 0.01$ & $11.82 \pm 0.69$ & $-20.8 \pm 0.7$ & - & 4 \\
\hline Offshore, 0 to $0.5 \mathrm{~cm}$ & $1 \mathrm{~km}$ offshore & $0.77 \pm 0.28$ & $0.08 \pm 0.03$ & $11.89 \pm 8.31$ & $-21.5 \pm 1.1$ & - & 5 \\
\hline POM & $1 \mathrm{~km}$ offshore & - & - & - & $-21.1 \pm 1.5$ & $3.6 \pm 2.1$ & 3 \\
\hline \multirow[t]{2}{*}{ MPB } & Unimpacted & - & - & - & $-25.2 \pm 1.0$ & - & 6 \\
\hline & Impacted & - & - & - & $-21.5 \pm 1.3$ & - & 6 \\
\hline
\end{tabular}

* Values were taken from Harada et al. (2019).
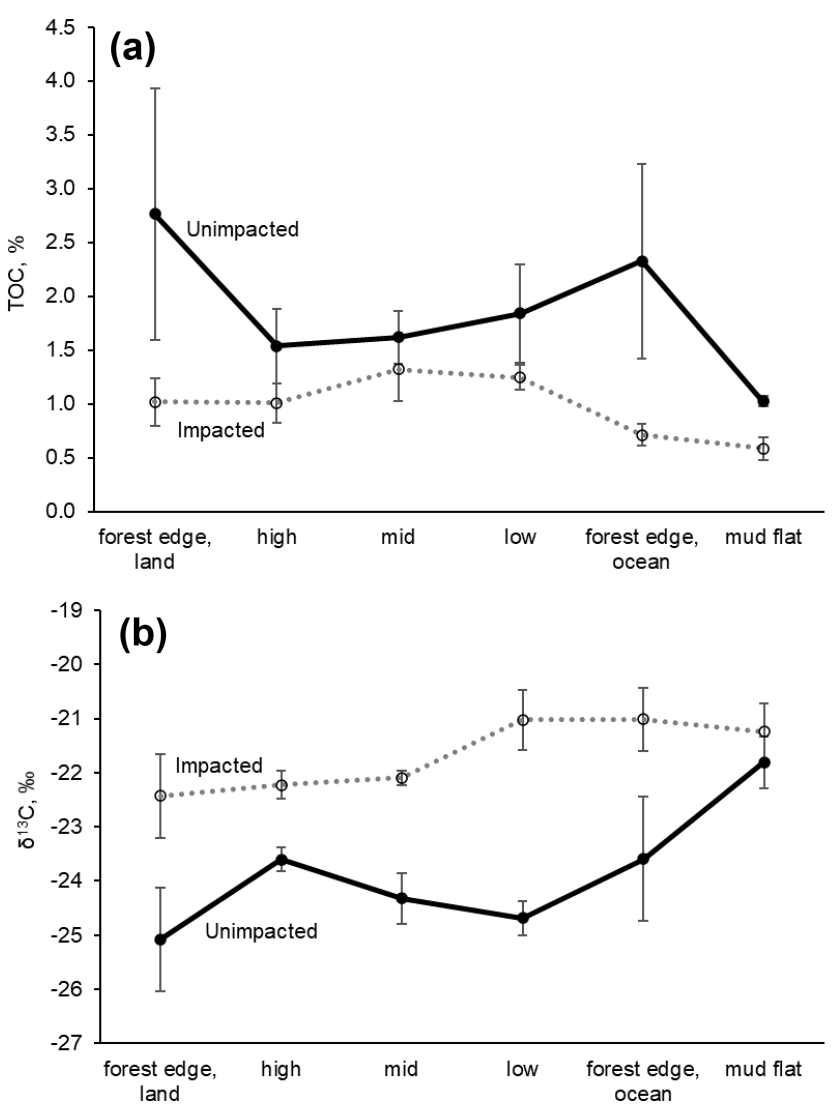

Figure 4. C elemental and isotopic compositions of surface $(<0.5 \mathrm{~cm})$ sediment along the unimpacted reference transects vs. impacted transects ( $n=3$ per data point). All samples were collected in 2018, 32 months after the dieback. Error values are SE. (a) Sediment TOC, \%. (b) Sediment $\delta^{13} \mathrm{C}$ values, \%o. filter feeder $\delta^{13} \mathrm{C}$ values did not differ between the two forests (ANOVA $F_{1,8}=1.719, p=0.212$ ), but the $\delta^{15} \mathrm{~N}$ and $\delta^{34} \mathrm{~S}$ values differed significantly between the two forests (ANOVA $p<0.05$ ). The effect of time was significant for the leaf feeder $\delta^{34} \mathrm{~S}$ values, the grazer $\delta^{15} \mathrm{~N}$ values, the filter feeder $\delta^{15} \mathrm{~N}$ and $\delta^{13} \mathrm{C}$ values (ANOVA $p<0.05$ ). In 2018, leaf feeder $\delta^{13} \mathrm{C}$ values, grazer $\delta^{34} \mathrm{~S}$ values and algae feeder $\delta^{34} \mathrm{~S}$ values significantly differed between the impacted and unimpacted sites (Turkey post hoc test, $p<0.05$ ), showing no recovery of the invertebrate fauna $\delta^{13} \mathrm{C}$ and $\delta^{34} \mathrm{~S}$ status 32 months after the dieback event. However, $\delta^{15} \mathrm{~N}$ values became similar between the two forests in 2018 (Fig. 5).

\subsection{Compound-specific isotope analysis of amino acid carbon}

The samples collected in 2017 were further measured for carbon isotopic compositions in individual essential amino acids. $\delta^{13} \mathrm{C}_{\mathrm{EAA}}$ values corresponded to the bulk $\delta^{13} \mathrm{C}$ values, with the samples from the impacted site consistently showing higher values than those from the unimpacted forest (Table 4 and Fig. 6). The pattern of normalised $\delta^{13} \mathrm{C}$ among five EAAs (Lys, Ile, Val, Leu and Phe) for all the consumers did not differ between the two forests $(p>0.05$; Table 4 and Fig. S1 in the Supplement). The $\delta^{13} \mathrm{C}_{\mathrm{EAA}}$ pattern of mangrove leaves did not differ between the forests, regardless of the substantial bulk isotope difference between the unimpacted $(-26.7 \pm 2.2 \%$ ) and impacted $(-25.4 \pm 0.1 \%$ o $)$ forests (Table 4). This isotope pattern was similar for all four feeding groups as well as for the MPB samples (Figs. 6 and S1). 
Table 4. Bulk $\delta^{13} \mathrm{C}$ values, mean $\delta^{13} \mathrm{C}$ values of five EAAs ( $\%$ ) and differences $(\Delta, \%$ ) between the two forests in 2017,20 months after the dieback (mean $\pm \mathrm{SD})$.

\begin{tabular}{|c|c|c|c|c|c|c|c|c|}
\hline Group & Taxa & Forest & $\begin{array}{r}\text { Bulk } \delta^{13} \mathrm{C}, \\
\% o\end{array}$ & $\begin{array}{r}\text { Mean } \delta^{13} \mathrm{C} \\
\text { of five } \\
\text { EAAs, \%o }\end{array}$ & $n$ & $\begin{array}{r}\Delta \text { Bulk } \\
\delta^{13} \mathrm{C}, \\
\% o\end{array}$ & $\begin{array}{r}\Delta \text { Mean } \\
\delta^{13} \mathrm{C} \text { of five } \\
\text { EAAs, } \% \text { o }\end{array}$ & $\begin{array}{r}\text { Permanova } \\
p \text { value }\end{array}$ \\
\hline Algal feeder & Tubuca signata & $\begin{array}{l}\text { Unimpacted } \\
\text { Impacted }\end{array}$ & $\begin{array}{l}-17.1 \pm 1.4 \\
-15.4 \pm 1.4\end{array}$ & $\begin{array}{l}-21.9 \pm 1.5 \\
-20.5 \pm 1.8\end{array}$ & $\begin{array}{l}3 \\
3\end{array}$ & 1.7 & 1.4 & 0.90 \\
\hline Leaf feeder & $\begin{array}{l}\text { Parasesarmal } \\
\text { Episesarma }\end{array}$ & $\begin{array}{l}\text { Unimpacted } \\
\text { Impacted }\end{array}$ & $\begin{array}{l}-21.4 \pm 1.5 \\
-18.3 \pm 0.2\end{array}$ & $\begin{array}{l}-25.3 \pm 1.6 \\
-23.9 \pm 0.1\end{array}$ & $\begin{array}{l}3 \\
2\end{array}$ & 3.1 & 1.4 & 0.40 \\
\hline Grazer & Telescopium telescopium & $\begin{array}{l}\text { Unimpacted } \\
\text { Impacted }\end{array}$ & $\begin{array}{l}-18.2 \pm 1.9 \\
-16.7 \pm 1.3\end{array}$ & $\begin{array}{l}-24.0 \pm 1.8 \\
-22.2 \pm 1.1\end{array}$ & $\begin{array}{l}3 \\
3\end{array}$ & 1.5 & 1.8 & 0.80 \\
\hline Filter feeder & Crassostrea (oyster) & $\begin{array}{l}\text { Unimpacted } \\
\text { Impacted }\end{array}$ & $\begin{array}{l}-19.3 \pm 0.4 \\
-19.0 \pm 0.8\end{array}$ & $\begin{array}{l}-22.8 \pm 0.2 \\
-22.9 \pm 0.3\end{array}$ & $\begin{array}{l}2 \\
2\end{array}$ & 0.3 & 0.1 & 0.33 \\
\hline Mangrove & Avicennia marina & $\begin{array}{l}\text { Unimpacted } \\
\text { Impacted }\end{array}$ & $\begin{array}{l}-26.7 \pm 2.2 \\
-25.4 \pm 0.1\end{array}$ & $\begin{array}{l}-28.8 \pm 0.6 \\
-27.0 \pm 0.3\end{array}$ & $\begin{array}{l}2 \\
2\end{array}$ & 1.3 & 1.8 & 0.67 \\
\hline MPB & & $\begin{array}{l}\text { Unimpacted } \\
\text { Impacted }\end{array}$ & $\begin{array}{l}-25.4 \pm 0.8 \\
-20.9 \pm 1.2\end{array}$ & $\begin{array}{l}-27.4 \\
-20.7\end{array}$ & $\begin{array}{l}1 \\
1\end{array}$ & 4.5 & 6.7 & - \\
\hline
\end{tabular}
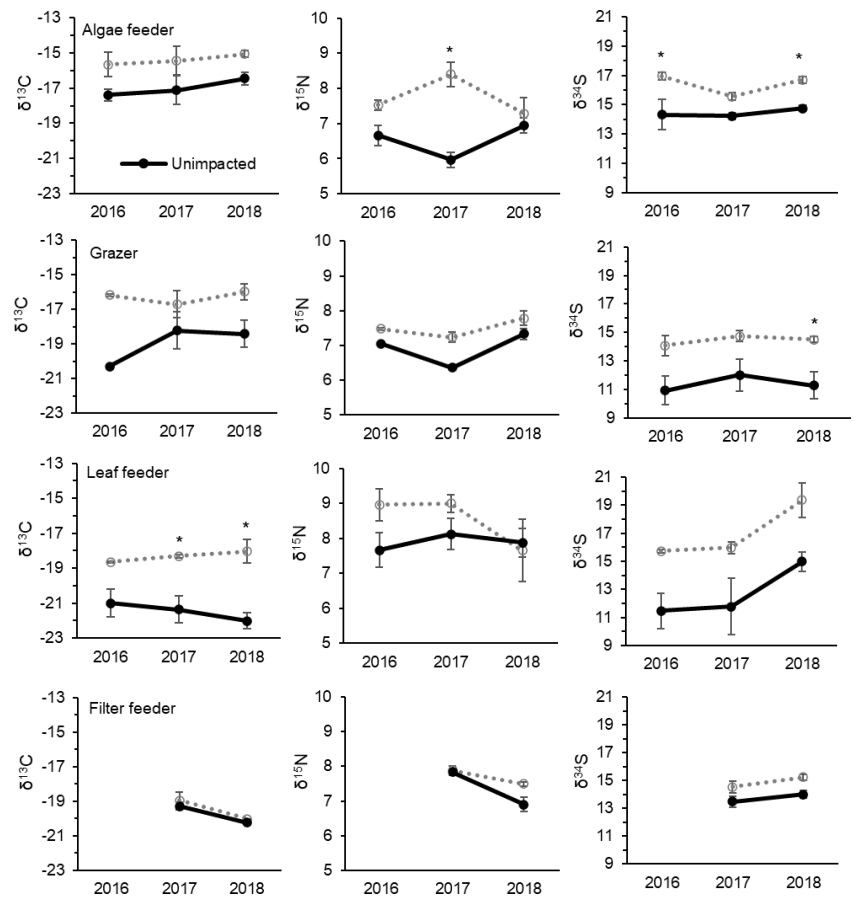

Figure 5. Changes in CNS isotopic compositions of mangrove macrofaunal groups with four different feeding modes from 2016, 2017 and 2018 (i.e. 8, 20 and 32 months after the event) between the unimpacted reference and impacted mangrove forest sites. Error bars are $\pm \operatorname{SE}\left(n=2\right.$ to 6 per data point). An asterisk $\left(^{*}\right)$ indicates a significant difference in the year. Mean \pm SE values and sample sizes are also provided in Table S4.

\section{Discussion}

\subsection{Mangroves}

The recovery of mangrove forests from tree mortality events caused by disturbances such as cyclones generally relies upon the recruitment of seedlings (Smith et al., 1994; Krauss and Osland, 2019). Subsequently, degraded habitats with a reduced seed pool, production and delivery, e.g. by habitat fragmentation, may show slower forest recovery (Milbrandt et al., 2006). The establishment of seedlings may also be inhibited by persistent inundation due to a decreased sediment elevation (Cahoon et al., 2003; Asbridge et al., 2018). Mangroves are resilient ecosystems and may recover quickly from natural disturbances (Sherman et al., 2001), but in some cases, full recovery may take decades (Imbert et al., 2000; Connolly et al., 2020). Further, mangrove degradation may be followed by fast colonisation of non-mangrove herbaceous species, e.g. succulent saltmarsh (Mbense et al., 2016; McKee et al., 2007; Rashid et al., 2009). However, this was not largely evident from our study site. In both mangrove forests at the Gulf of Carpentaria site, the density of mangrove seedlings and samplings significantly increased throughout the period from 2016 to 2018, suggesting that recovery was starting to occur in some areas within 32 months after the dieback and propagule pool was available in the vicinity. The increase in seedling and sampling density at the unimpacted site was unexpected, but this indicates that there was some stress at the unimpacted site during the dieback period, and/or the temporal variability of seedling and sampling density was high at the site.

The substantial differences in CNS isotopic compositions in A. marina occurring between the two sites suggested dif- 

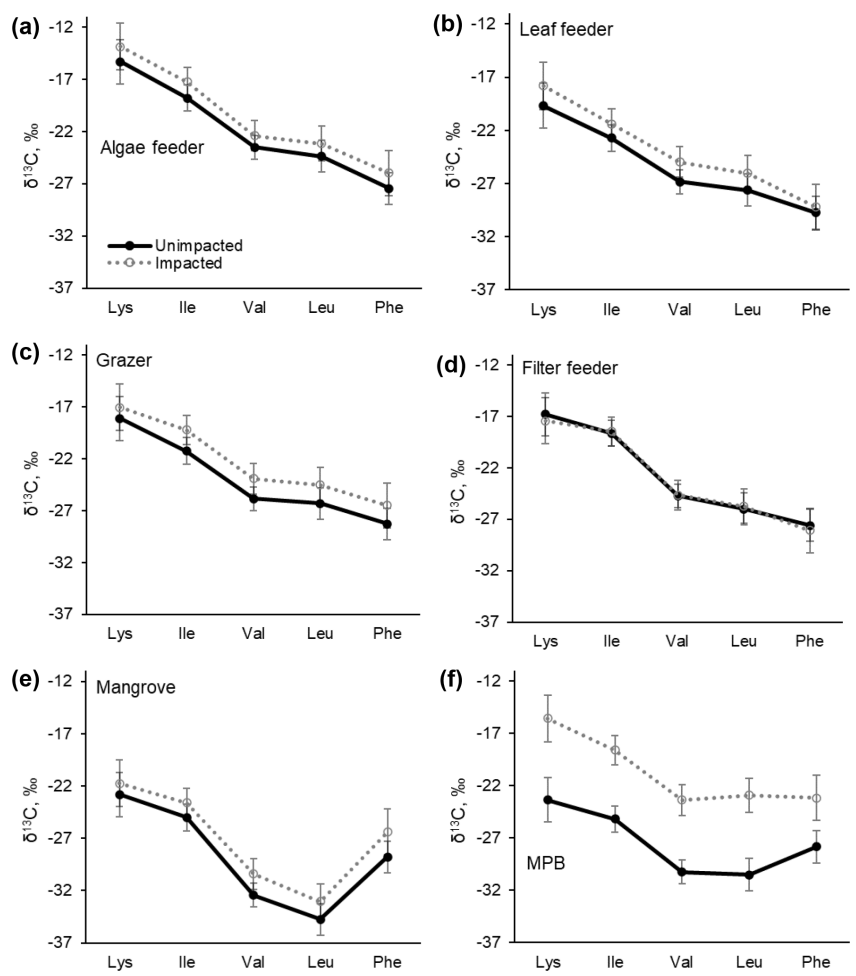

Figure 6. $\mathrm{C}$ isotopic compositions in essential amino acids (EAAs) for four mangrove consumer groups and resources including mangrove leaves (A. marina) and MPB from the unimpacted and impacted mangrove sites during 2017 (20 months after the dieback). While there are clear offsets in individual $\delta^{13} \mathrm{C}_{\mathrm{EAA}}$ values between the two forests, normalised $\delta^{13} \mathrm{C}_{\mathrm{EAA}}$ fingerprint patterns as per Larsen (2009) shown in Fig. S1 did not differ (PERMANOVA $p>0.05$, Table 3 ). Error bars show $\pm \mathrm{SD}$. The data are provided in Table S5.

ferences in the environmental conditions and biogeochemical processes that were possibly associated with the mangrove mortality effect. The leaf $\delta^{13} \mathrm{C}$ values in the impacted forest were relatively enriched in ${ }^{13} \mathrm{C}$. This $\mathrm{C}$ isotope pattern may be due to reduced stomatal conductance that causes lower internal carbon dioxide concentrations and lower carbon isotope fractionation (Farquhar et al., 1989; Lin and Sternberg, 1992a; Lin and Sternberg, 1992b). Higher leaf $\delta^{13} \mathrm{C}$ values can also be associated with increased carboxylation efficiency associated with higher nutrients, e.g. $\mathrm{N}$ in leaves (Cordell et al., 1999) and thicker leaves with higher internal resistance to carbon dioxide diffusion. Younger leaves can show higher $\delta^{13} \mathrm{C}$ values than aged leaves due to ${ }^{13} \mathrm{C}$ enriched fractions (e.g. carbohydrates) transported from older autotrophic leaves to more heterotrophic young leaves (Werth et al., 2015). Leaves exposed to full sun can show higher $\delta^{13} \mathrm{C}$ values than shaded leaves (Farquhar et al., 1989). $\delta^{13} \mathrm{C}$ values can also vary among different plant tissues in A. marina (Kelleway et al., 2018). Leaf N (\%) did not differ between the two forests, suggesting that the two sites may have similar plant $\mathrm{N}$ availability. Previous studies show additions of nutrients such as $\mathrm{N}$ and/or $\mathrm{P}$ did not play a considerable role in mangrove leaf $\delta^{13} \mathrm{C}$ variations (McKee et al., 2002), but salinity played an important role (Lin and Sternberg, 1992b). For example, leaf $\delta^{13} \mathrm{C}$ values of $A$. $m a-$ rina at a lower salinity site were relatively depleted in ${ }^{13} \mathrm{C}$ and averaged about $-31 \%$ (Kelleway et al., 2018). Overall, higher leaf $\delta^{13} \mathrm{C}$ values in the impacted forest likely suggest that there are chronic stresses associated with the dieback event that reduced stomatal conductance. Such environmental stresses may include hypersalinisation of sediments and hydric, thermal and radiant stresses following canopy losses that cause higher evaporation and lower water availability. The leaves at the unimpacted site were largely depleted in ${ }^{13} \mathrm{C}$, suggesting that there was higher water availability at the unimpacted site, possibly associated with regional variability in groundwater flows, e.g. Sippo et al. (2020).

Leaf $\delta^{15} \mathrm{~N}$ values varied more in the impacted (ranged from $-0.9 \%$ to $6.7 \%$ ) than in the unimpacted forest (ranged from $2.9 \%$ to $6.2 \%$ ), but the means were similar $(4.3 \pm 1.9 \%$ or the impacted and $4.4 \pm 0.8 \%$ or for the unimpacted), suggesting that two sites have similar background $\delta^{15} \mathrm{~N}$ conditions. Generally, leaf $\delta^{15} \mathrm{~N}$ varies due to $\mathrm{N}$ sources, microbial processes that enrich or deplete ${ }^{15} \mathrm{~N}$ in soil or water, and isotope fractionation during plant $\mathrm{N}$ uptake. Previous studies showed that in pristine mangrove forests, leaf $\delta^{15} \mathrm{~N}$ values generally range around $-2 \%$ o to $3 \%$ (Fry and Smith, 2002; Smallwood et al., 2003). Such low $\delta^{15} \mathrm{~N}$ values may reflect long-term $\mathrm{N}$ fixation inputs (e.g. around $0 \%$ ) (Fogel et al., 2008) and marine nitrate inputs (Dore et al., 2002). Much higher $\delta^{15} \mathrm{~N}$ values (>10\%o) may be associated with anthropogenic $\mathrm{N}$ inputs (Fry and Cormier, 2011). Our sites showed moderate $\delta^{15} \mathrm{~N}$ values (about $4 \%$ ), suggesting that in addition to $\mathrm{N}$ fixation inputs and marine $\mathrm{N}$ inputs, there may be considerable microbial ${ }^{15} \mathrm{~N}$ enrichment in dissolved inorganic nitrogen pools of ammonium and nitrate. The higher variability in leaf $\delta^{15} \mathrm{~N}$ in the impacted forest suggests higher variability in processes affecting the $\delta^{15} \mathrm{~N}$ status of available N. For example, changes to sediment conditions including redox transitions and soil moisture content following the dieback may have affected microbial processes of $\mathrm{N}$, whereas the unimpacted forest may have had more stable sediment conditions and $\mathrm{N}$ processes. Isotope fractionation during plant $\mathrm{N}$ uptake may also be an explanation for leaf $\delta^{15} \mathrm{~N}$ variability (Fry et al., 2000), but such fractionation is poorly known for mangroves. A study reported that additions of $\mathrm{P}$ nutrients increased $\mathrm{N}$ demand and decreased ${ }^{15} \mathrm{~N}$ fractionation (McKee et al., 2002); however, as we did not measure $\mathrm{P}$, we could not determine whether this was the case.

Leaf $\delta^{34} \mathrm{~S}$ values differed considerably between the two forests, with the impacted forest generally having higher values $(13.5 \pm 5.4 \%$ o, range $7.7 \%$ o to $23.3 \%$ o) than the unimpacted forest $(12.6 \pm 5.6 \%$, range $5.0 \%$ to $21.9 \%$ o). Leaf $\delta^{34} \mathrm{~S}$ values showed trends along the six transects, with val- 
ues decreasing from the upper to lower intertidal zones. Based on previous studies, mangrove leaf $\delta^{34} \mathrm{~S}$ values generally vary between $-20 \%$ and $20 \%$ (Okada and Sasaki, 1995, 1998; Fry and Smith, 2002). Higher $\delta^{34}$ S values are likely associated with seawater sulfate, which is ${ }^{34} \mathrm{~S}$ enriched (i.e. $21 \%$ ) and due to a large isotope fractionation (up to $70 \%$ ) during sulfate reduction (Kaplan and Rittenberg, 1964). Lower $\delta^{34} \mathrm{~S}$ values are likely associated with sedimentary sulfide $\mathrm{S}$ that is ${ }^{34} \mathrm{~S}$ depleted, for example, $-21 \%$ o (Okada and Sasaki, 1995). Leaf $\delta^{34} \mathrm{~S}$ values of around $14 \%$ o to $18 \%$ o suggest mangrove incorporations of seawater sulfate $\mathrm{S}\left(\delta^{34} \mathrm{~S}, \sim 21 \%\right.$ o $)$ with only a small isotopic fractionation occurring through absorption and assimilation steps (Okada and Sasaki, 1995). Plants generally show $\delta^{34} \mathrm{~S}$ values slightly lower than source sulfate $\mathrm{S}$ by an average of $-1.5 \%$ (Trust and Fry, 1992). Low leaf $\delta^{34} \mathrm{~S}$ values, for instance the lowest value of $5 \%$ found in the unimpacted site, suggest that the most probable source of this ${ }^{34} \mathrm{~S}$-depleted $\mathrm{S}$ is sulfide oxidation, followed by mixing with seawater sulfate. Low $\delta^{34} \mathrm{~S}$ values in mangrove root vascular tissues may indicate assimilation and oxidation of sulfide, potentially to reduce their toxic sulfide exposure (Fry et al., 1982; Raven et al., 2019 ), with a reported isotope effect of $-5.2 \%$ for the nonbiological oxidation of sulfide (Fry et al., 1988) and a smaller $+1-3 \%$ effect for anaerobic oxidation of sulfide by photosynthetic bacteria (Fry et al., 1984). An explanation for our observed $\delta^{34} \mathrm{~S}$ pattern may be lower plant incorporation of sulfide $S$ in the impacted site and also in the higher intertidal zones where we expect that mangrove sediment is relatively more oxidised, and the production of sulfide may be lower due to lower sulfate reduction.

\subsection{Sediment}

In healthy mangrove forests, the fate of $\mathrm{C}$ fixed by primary producers includes burial within the sediment, atmospheric emissions and outwelling to the ocean (Maher et al., 2018), but how mangrove mortality affects such processes is poorly understood. In most cases, $\mathrm{C}$ within mangrove sediment decreases following forest loss due to degradation with increased $\mathrm{CO}_{2}$ emissions (Otero et al., 2017; Adame et al., 2018). Lower TOC (\%) and higher sediment $\delta^{13} \mathrm{C}$ values in the impacted forest are probably related to sediment $\mathrm{C}$ loss and lower autochthonous $\mathrm{C}$ inputs (i.e. leaf litter) following the mangrove mortality event. Consistent with this, the sediment $\mathrm{N}(\%)$ and $\delta^{15} \mathrm{~N}$ data showed a similar pattern, suggesting $\mathrm{N}$ loss and degradation. The surface sediment varied more than the subsurface fraction. This is probably because the surface fraction is generally more aerobic and remineralisation of organic matter occurs more rapidly (Burdidge, 2011). Sediment $\delta^{13} \mathrm{C}$ and ${ }^{15} \mathrm{~N}$ values can increase during degradation of sediment organic matter following mangrove loss (Adame and Fry, 2016; Adame et al., 2018). Changes in sediment $\mathrm{C}$ and $\mathrm{N}$ may also be associated with root turnover. The MPB $\delta^{13} \mathrm{C}$ values significantly differed, with those from the impacted being higher than the unimpacted. The higher values probably indicate lower respiratory inputs of $\mathrm{CO}_{2}$ from mangroves (Maher et al., 2013b). Our findings here are consistent with the finding of Sippo et al. (2019) that changes to oceanic carbon outwelling rates following mangrove loss are likely associated with a gradual loss of sediment carbon; similar to our finding of increased sediment $\delta^{13} \mathrm{C}$ values in the impacted site, an isotope effect may have been due to loss of sediment mangrove $\mathrm{C}$ and/or replacement of mangrove peats with marine sediment.

\subsection{Fauna}

CNS isotopic compositions of consumers including an algae feeder, a grazer and a leaf feeder from the impacted site were more enriched in ${ }^{13} \mathrm{C},{ }^{15} \mathrm{~N}$ and ${ }^{34} \mathrm{~S}$. These differences remained consistent throughout the three sampling periods of 2016, 2017 and 2018. Consistent with the findings from mangrove leaves, MPB and soil, the data suggested substantial changes in cycling of CNS associated with the mangrove mortality event. At the impacted site, consumers were more ${ }^{13} \mathrm{C}$ enriched, likely due to the loss of ${ }^{13} \mathrm{C}$-depleted mangrove organic matter. Consumer $\delta^{13} \mathrm{C}$ values can change due to changes to available organic matter, altered feeding dependencies and changes to organic matter $\delta^{13} \mathrm{C}$ values. In our case, MPB $\delta^{13} \mathrm{C}$ values changed significantly, likely due to changes to organic matter respiratory inputs and/or altered light environment and soil moisture contents that may change isotopic fractionation during carbon fixation. The consumer $\delta^{13} \mathrm{C}$ values and their ranges at our study site are fairly consistent with the reported mangrove consumer $\delta^{13} \mathrm{C}$ values elsewhere (e.g. Lee, 2000; Bouillon et al., 2002; Demopoulos et al., 2007). The typical trophic enrichment factor for carbon isotopes in small invertebrates is about $+1 \%$ o (Vander Zanden and Rasmussen, 2001; McCutchan et al., 2003). Lower consumer $\delta^{13} \mathrm{C}$ values are generally associated with mangrove detritus that is depleted in ${ }^{13} \mathrm{C}$. Typical mangrove leaf-eating sesarmid crab species generally have tissue $\delta^{13} \mathrm{C}$ values within about $+5 \%$ from mangrove detritus (Bui and Lee, 2014). Higher $\delta^{13} \mathrm{C}$ values of consumers are generally tied to MPB. Our MPB endmember $\delta^{13} \mathrm{C}$ values of $-25.2 \%$ o for the unimpacted site and $-21.5 \%$ for the impacted site did not match with the consumer $\delta^{13} \mathrm{C}$ values (around $-15 \%$ to $-14 \%$ ), suggesting our characterisation of MPB endmember $\delta^{13} \mathrm{C}$ values was incomplete. This is probably because MPB can vary substantially within mangrove ecosystems (Bouillon et al., 2008), and consumers may be preferentially assimilating more ${ }^{13} \mathrm{C}$ enriched fractions of MPB, for example, diatom and/or filamentous cyanobacteria that can range about $-15 \%$ o to $-20 \%$ (Craig, 1953; Fry and Wainright, 1991). The leaf feeders were relatively depleted in ${ }^{13} \mathrm{C}$, with $\delta^{13} \mathrm{C}$ values of about $-21 \%$ o to $-18 \%$, likely due to some use of mangrove leaves. Due to difficulties obtaining representative endmembers, mixing analysis was not achieved using these data to quantify feeding dependencies. 
However, MPB probably played an important dietary role in both forests because the difference in MPB $\delta^{13} \mathrm{C}$ values between the two forests were reflected in the difference in the consumers $\delta^{13} \mathrm{C}$ values between the two forests (Harada et al. 2019).

Consistent with the mangrove leave $\delta^{34} \mathrm{~S}$ values, the consumer $\delta^{34} \mathrm{~S}$ values also indicated possible changes to $\mathrm{S}$ cycling. The consumer $\delta^{34} \mathrm{~S}$ values were generally higher in the impacted site (range $13.4 \%$ to $21.7 \%$ ) than in the unimpacted site (range $8.2 \%$ to $16 \%$ ), suggesting lower sulfate reduction with decreased sulfide inputs at the impacted site. Fixation of sulfate by phytoplankton occurs with a small isotope effect, around 1\%o to 2\%o (Fry, 2006); therefore phytoplankton $\delta^{34} \mathrm{~S}$ values from the coastal ocean are generally close to the seawater sulfate $\mathrm{S}$ value of $21 \%$. MPB generally have lower $\delta^{34} \mathrm{~S}$ values than phytoplankton, e.g. near $10 \%$ o for MPB in a mangrove ecosystem (Harada et al., unpublished), likely due to some use of sedimentary sulfide $\mathrm{S}$ (depleted in ${ }^{34} \mathrm{~S}$ ). Our consumer $\delta^{34} \mathrm{~S}$ values were lower than $21 \%$, suggesting some use of MPB as well as mangrove detritus. The consumer $\delta^{15} \mathrm{~N}$ also indicates possible changes to $\mathrm{N}$ cycling, with the consumer in the impacted site generally having higher values than those from in the unimpacted site. The higher $\delta^{15} \mathrm{~N}$ values are likely associated with degradation of organic matter, microbial ${ }^{15} \mathrm{~N}$ enrichment in dissolved inorganic $\mathrm{N}$ during degradation and lower $\mathrm{N}$ fixation inputs that typically show low $\delta^{15} \mathrm{~N}$ values. While the $\delta^{13} \mathrm{C}$ and $\delta^{34} \mathrm{~S}$ values consistently differed between the two forests during the 2-year survey, the $\delta^{15} \mathrm{~N}$ values started showing matches between the two forests in 2018 , likely suggesting recovery of $\delta^{15} \mathrm{~N}$ status to the background conditions, and/or that the recovery of $\mathrm{N}$ may be faster than $\mathrm{C}$ and $\mathrm{S}$ elements. This may be the case as mangrove ecosystems are generally $\mathrm{N}$ limited (Reef et al., 2010), and circulation of $\mathrm{N}$ elements is faster than those of $\mathrm{C}$ and $\mathrm{S}$ elements.

\subsection{Compound-specific isotope analysis of amino acids}

It is considered that environmental resources such as vascular plants and microalgae have a different $\delta^{13} \mathrm{C}$ pattern ("fingerprint") in AAs due to differing biosynthesis of AAs (Larsen et al., 2009; Larsen et al., 2013). It is also reported that $\delta^{13} \mathrm{C}$ patterns are largely unaffected by environmental conditions. For example, $\delta^{13} \mathrm{C}_{\mathrm{AA}}$ patterns of the marine diatom Thalassiosira weissflogii did not respond to changing environmental conditions such as light, salinity, temperature and $\mathrm{pH}$, despite substantial changes in bulk $\delta^{13} \mathrm{C}$ values (Larsen et al., 2015). A similar isotope pattern was reported for seagrass Posidonia oceanica and the giant kelp Macrocystis pyrifera, which showed consistent $\delta^{13} \mathrm{C}_{\mathrm{AA}}$ patterns despite varying season and growth conditions (Larsen et al., 2013). The $\delta^{13} \mathrm{C}_{\mathrm{AA}}$ patterns in producers, especially those of essential amino acids $\left(\delta^{13} \mathrm{C}_{\mathrm{EAA}}\right)$, can be reflected in consumer tissues with little isotope effect. This is because animals obtain EAAs from their diet and EAA fractions are thought to be directly assim- ilated (McMahon et al., 2010). These general expectations were reasonably met in our $\delta^{13} \mathrm{C}_{\mathrm{EAA}}$ dataset. Normalised $\delta^{13} \mathrm{C}_{\mathrm{EAA}}$ patterns of our producer samples including mangrove leaves (yellow leaves of A. marina) and MPB did not differ between the two sites despite differing environmental conditions and substantial differences in bulk $\delta^{13} \mathrm{C}$ values (Table 4, Figs. 6 and S1). Furthermore, the consumer $\delta^{13} \mathrm{C}_{\text {EAA }}$ patterns also did not differ between the two sites. (Figs. 6 and S1). These findings did not support changes to feeding dependency following mangrove loss but suggested that the overall differences in the consumer bulk $\delta^{13} \mathrm{C}$ values were most likely driven by differences in the resource organic matter $\delta^{13} \mathrm{C}$ values, e.g. changes to MPB $\delta^{13} \mathrm{C}$ values that were likely associated with lower mangrove $\mathrm{C}$ fixation or respiratory inputs following the mangrove mortality. Furthermore, such findings indicate that the reported substantial change to the mangrove benthic faunal assemblage following the mangrove loss (Harada et al., 2019) was probably driven more by modification of physical habitat structure than changes in the use of food resources.

\section{Conclusions}

Reporting rare and extreme biological events can be complicated because in many cases they may occur suddenly; therefore drawing comparisons between pre- and post-event conditions remains a challenge. Our field investigations using traditional ecological techniques combined with SIA measured the initial dieback and also early recovery of an impacted mangrove ecosystem and compared an adjacent unimpacted reference system. Although the unimpacted and impacted forests were not replicated in this study, the difference between the two sites was clear. Mangrove seedling and sapling populations that increased during the period from 2016 to 2018 ( 8 to 32 months after the mortality event) in the impacted site suggest recovery of the mangrove vegetation. This also suggests that the environmental conditions at the impacted site are still conducive to the re-establishment of mangroves, allowing recruitment of seedlings and development of regrowth. However, mangrove leaves collected in the impacted site in 2018 showed relatively higher $\delta^{13} \mathrm{C}$ values $(-25.8 \pm 1.0 \%)$ that are probably associated with continued water stress. Invertebrates from the impacted site representing the feeding types of grazing, leaf feeding and algae feeding were more enriched in ${ }^{13} \mathrm{C},{ }^{15} \mathrm{~N}$ and ${ }^{34} \mathrm{~S}$ relative to those from the unimpacted site. For example, they were more ${ }^{13} \mathrm{C}$ enriched at the impacted site, by $1.7 \% \circ-4.1 \%$, and the difference did not change over the study period. Overall, our stable CNS isotope data supported the hypothesis that changes to biogeochemical processes occur following the mangrove mortality. These changes include lower mangrove $\mathrm{C}$ fixation and respiration, lower $\mathrm{N}$ fixation, and lower sulfate reduction. However, our isotope data did not support the second hypothesis that the isotopic compositions change over time with re- 
Disturbance legacies of the forest dieback

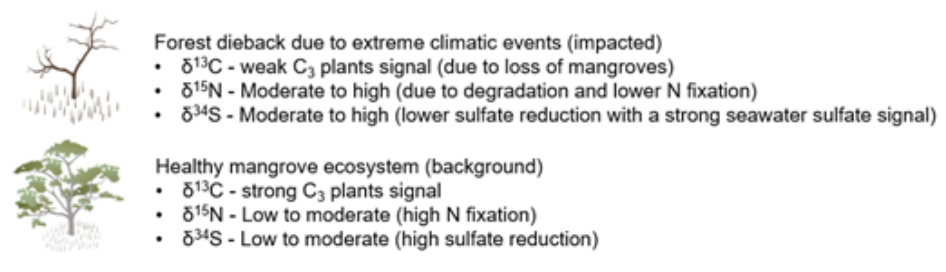

Predicted recovery scenarios with isotopic trajectories
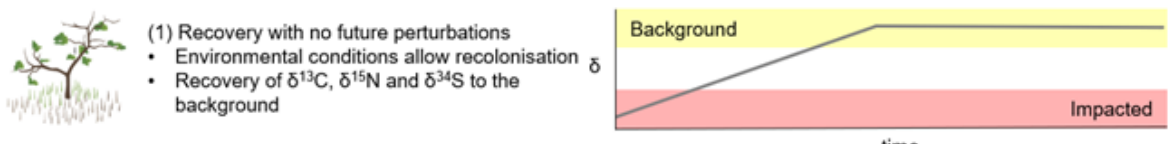

(2) Recovery with future perturbations

- Mangrove recolonisation and recovery of ${ }^{13} \mathrm{C}, \delta^{15} \mathrm{~N}$ and $\delta^{34} \mathrm{~S}$ driven by perturbations e.g. ENSO cycles

(3) Habitat becomes unsuitable for recolonisation

- Conditions not allow recolonisation e.g. due to

extreme climatic events

- Transformed into intertidal mudflats

- No recovery of isotopes
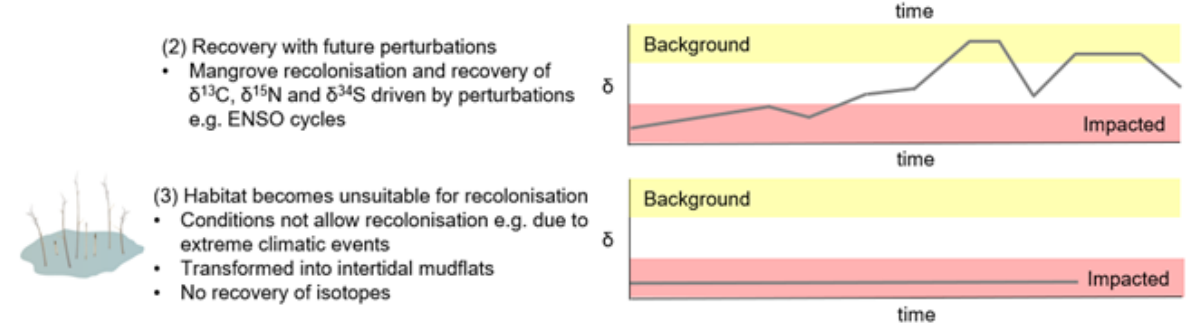

(4) Incomplete recovery

- Reduced habitat size and/or recolonised by other plants such as saltmarshes

- Incomplete recovery of $\delta^{13} \mathrm{C}, \delta^{15} \mathrm{~N}$ and $\delta^{34} \mathrm{~S}$

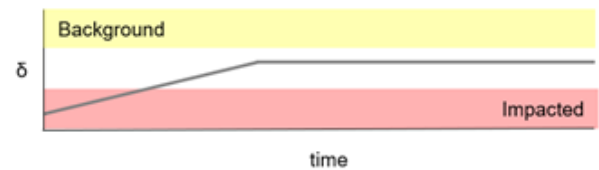

Figure 7. A conceptual diagram showing the ecological and biogeochemical legacy of the mangrove forest dieback in the Gulf of Carpentaria and four predicted recovery scenarios of the mangrove ecosystem with isotopic trajectories ( $\delta$ represents the isotope values of animals, plants and sediment).

covery of mangrove vegetation. Recovery of biogeochemical processes was not evident even after 2 years, suggesting an ongoing impact of the mortality event. An exception was that $\mathrm{N}$ cycle recovery may be occurring faster.

Considering that the environmental conditions at the site play an important role in facilitating recolonisation of mangroves, we conceptualise the recovery of the mangrove forest under four different scenarios to give insight into the ecological and biogeochemical consequences of changing forest conditions (Fig. 7): (1) the forest recovers with mangroves being able to recolonise at the site without future perturbations; (2) the forest recovers with future perturbations such as climatic events (for example, mangrove recolonisation is driven by events such as ENSO cycles); (3) the forest does not recover and is transformed into intertidal mudflats; and (4) the forest recovers partially at the site and in a reduced size and/or is recolonised by other plants such as saltmarshes (e.g. mangroves only recolonise in the lower intertidal zone). Each of these scenarios will have a distinct isotopic trajectory for $\mathrm{C}, \mathrm{N}$ and $\mathrm{S}$. While these are likely scenarios and there might be other possibilities, comparing the impacted forest and an adjacent unimpacted reference forest can help us quantify the recovery. Continued monitoring of the postdieback forest would be required to predict the long-term trajectory of ecosystem recovery and how ongoing climate change and extreme climatic events affect the recovery of mangroves in the impacted region. In such a long-term investigation, SIA is a powerful tool, capable of tracking changes in biogeochemical processes over time. As such, it is of great assistance in ecosystem analyses and detecting the underlying biological mechanisms that drive changes and recovery.

Data availability. The datasets used in this paper are available in the Supplement.

Supplement. The supplement related to this article is available online at: https://doi.org/10.5194/bg-17-5599-2020-supplement.

Author contributions. The study was conceptualised by all authors. Writing was led by $\mathrm{YH}$ and contributed to by all. Field surveys were executed by DTM, JZS, LCJ, AJB and YH. Data compilation and analysis was coordinated by $\mathrm{YH}$ and contributed to by all.

Competing interests. The authors declare that they have no conflict of interest. 
Acknowledgements. We acknowledge support from Yota Harada for the Holsworth Wildlife Research Endowment from the Equity Trustees Charitable Foundation and the Ecological Society of Australia; Damien T. Maher from the Australian Research Council (DE1500100581, DP180101285); and Rod M. Connolly from the Global Wetlands Project. We thank Rad Bak and Vanessa Fry (Griffith University) for stable isotope analysis. Field work was assisted by Gloria Reithmaier, Kylie Maguire, Dylan Brown, Stephen R. Conrad, Ashly McMahon, Ceylena Holloway, Mitchell Call, Alice Gauthey, Geoff Balland and Julia Kalla. Matthew A. Hayes commented on and improved early versions of the manuscript.

Financial support. This research has been supported by the Holsworth Wildlife Research Endowment from the Equity Trustees Charitable Foundation and the Ecological Society of Australia, the Australian Research Council (grant nos. DE1500100581 and DP180101285), and the Global Wetlands Project.

Review statement. This paper was edited by Yakov Kuzyakov and reviewed by Martin Zimmer and two anonymous referees.

\section{References}

Abrantes, K. G., Johnston, R., Connolly, R. M., and Sheaves, M.: Importance of Mangrove Carbon for Aquatic Food Webs in WetDry Tropical Estuaries, Estuar. Coast., 38, 383-399, 2015.

Adame, M. and Fry, B.: Source and stability of soil carbon in mangrove and freshwater wetlands of the Mexican Pacific coast, Wetl. Ecol. Manag., 24, 129-137, 2016.

Adame, M., Zakaria, R., Fry, B., Chong, V., Then, Y., Brown, C., and Lee, S. Y..: Loss and recovery of carbon and nitrogen after mangrove clearing, Ocean Coast. Manage., 161, 117-126, 2018.

Asbridge, E., Lucas, R., Ticehurst, C., and Bunting, P.: Mangrove response to environmental change in Australia's Gulf of Carpentaria, Ecol. Evol., 6, 3523-3539, 2016.

Asbridge, E., Lucas, R., Rogers, K., and Accad, A.: The extent of mangrove change and potential for recovery following severe Tropical Cyclone Yasi, Hinchinbrook Island, Queensland, Australia, Ecol. Evol., 8, 10416-10434, 2018.

Asbridge, E. F., Bartolo, R., Finlayson, C. M., Lucas, R. M., Rogers, K., and Woodroffe, C. D.: Assessing the distribution and drivers of mangrove dieback in Kakadu National Park, northern Australia, Estuar. Coast. Shelf S., 228, 106353, https://doi.org/10.1016/j.ecss.2019.106353, 2019.

Bernardino, A. F., Gomes, L. E. D. O., Hadlich, H. L., Andrades, R., and Correa, L. B.: Mangrove clearing impacts on macrofaunal assemblages and benthic food webs in a tropical estuary, Marine Pollut. Bull., 126, 228-235, 2018.

Bouillon, S., Koedam, N., Raman, A., and Dehairs, F.: Primary producers sustaining macro-invertebrate communities in intertidal mangrove forests, Oecologia, 130, 441-448, 2002.

Bouillon, S., Connolly, R. M., and Lee, S. Y.: Organic matter exchange and cycling in mangrove ecosystems: Recent insights from stable isotope studies, J. Sea Res., 59, 44-58, 2008.
Bui, T. H. H. and Lee, S. Y.: Does "You Are What You Eat" Apply to Mangrove Grapsid Crabs?, PLOS ONE, 9, e89074, https://doi.org/10.1371/journal.pone.0089074, 2014.

Burdige, D.: 5.09 Estuarine and coastal sediments-coupled biogeochemical cycling, Treatise on Estuarine and Coastal Science, 5, 279-308, 2011.

Cahoon, D. R., Hensel, P., Rybczyk, J., McKee, K. L., Proffitt, C. E., and Perez, B. C.: Mass tree mortality leads to mangrove peat collapse at Bay Islands, Honduras after Hurricane Mitch, J. Ecol., 91, 1093-1105, 2003.

Connolly, R. M., Connolly, F. N., and Hayes, M. A.: Oil spill from the Era: Mangroves taking eons to recover, Mar. Pollut. Bull., 153, 110965, https://doi.org/10.1016/j.marpolbul.2020.110965, 2020.

Cordell, S., Goldstein, G., Meinzer, F. C., and Handley, L. L.: Allocation of nitrogen and carbon in leaves of Metrosideros polymorpha regulates carboxylation capacity and $\delta^{13} \mathrm{C}$ along an altitudinal gradient, Funct. Ecol., 13, 811-818, 1999.

Coumou, D. and Rahmstorf, S.: A decade of weather extremes, Nat. Clim. Change, 2, 491-496, 2012.

Craig, H.: The geochemistry of the stable carbon isotopes, Geochim. Cosmochimica Ac., 3, 53-92, 1953.

Demopoulos, A. W., Fry, B., and Smith, C. R.: Food web structure in exotic and native mangroves: a Hawaii-Puerto Rico comparison, Oecologia, 153, 675-686, 2007.

Docherty, G., Jones, V., and Evershed, R. P.: Practical and theoretical considerations in the gas chromatography/combustion/isotope ratio mass spectrometry $\delta^{13} \mathrm{C}$ analysis of small polyfunctional compounds, Rapid Commun. Mass Sp., 15, 730-738, 2001.

Dore, J. E., Brum, J. R., Tupas, L. M., and Karl, D. M.: Seasonal and interannual variability in sources of nitrogen supporting export in the oligotrophic subtropical North Pacific Ocean, Limnol. Oceanogr., 47, 1595-1607, 2002.

Duke, N. C., Kovacs, J. M., Griffiths, A. D., Preece, L., Hill, D. J., Van Oosterzee, P., Mackenzie, J., Morning, H. S., and Burrows, D.: Large-scale dieback of mangroves in Australia's Gulf of Carpentaria: a severe ecosystem response, coincidental with an unusually extreme weather event, Marine Freshwater Res., 68 , 1816-1829, 2017.

Farquhar, G. D., Ehleringer, J. R., and Hubick, K. T.: Carbon isotope discrimination and photosynthesis, Annu. Rev. Plant Biol., 40, 503-537, 1989.

Fogel, M. L., Wooller, M. J., Cheeseman, J., Smallwood, B. J., Roberts, Q., Romero, I., and Meyers, M. J.: Unusually negative nitrogen isotopic compositions $\left(\delta^{15} \mathrm{~N}\right)$ of mangroves and lichens in an oligotrophic, microbially-influenced ecosystem, Biogeosciences, 5, 1693-1704, https://doi.org/10.5194/bg5-1693-2008, 2008.

Fry, B.: Stable isotope ecology, Springer, New York, NY, USA, 2006.

Fry, B. and Cormier, N.: Chemical Ecology of Red Mangroves, Rhizophora mangle, in the Hawaiian Islands1, Pac. Sci., 65, 219 235, 2011.

Fry, B. and Smith, T. J.: Stable isotope studies of red mangroves and filter feeders from the Shark River estuary, Florida, B. Mar. Sci., 70, 871-890, 2002.

Fry, B. and Wainright, S. C.: Diatom sources of ${ }^{13}$ C-rich carbon in marine food webs, Mar. Ecol.-Prog. Ser., 76, 149-157, 1991. 
Fry, B., Scalan, R. S., Winters, J. K., and Parker, P. L.: Sulphur uptake by salt grasses, mangroves, and seagrasses in anaerobic sediments, Geochim. Cosmochim. Ac., 46, 1121-1124, 1982.

Fry, B., Gest, H., and Hayes, J. M.: Isotope effects associated with the anaerobic oxidation of sulfide by the purple photosynthetic bacterium, Chromatium vinosum, FEMS Microbiol. Lett., 22, 283-287, 1984.

Fry, B., Ruf, W., Gest, H., and Hayes, J. M.: Sulfur isotope effects associated with oxidation of sulfide by $\mathrm{O}_{2}$ in aqueous solution, Chem. Geol., 73, 205-210, 1988.

Fry, B., Bern, A. L., Ross, M. S., and Meeder, J. F.: $\delta^{15} \mathrm{~N}$ Studies of Nitrogen Use by the Red Mangrove, Rhizophora mangle L. in South Florida, Estuar. Coast. Shelf S., 50, 291-296, 2000.

Harada, Y., Fry, B., Lee, S. Y., Maher, D. T., Sippo, J. Z., and Connolly, R. M.: Stable isotopes indicate ecosystem restructuring following climate-driven mangrove dieback, Limnol. Oceanogr., 65, 1251-1263, 2019.

Harris, T., Hope, P., Oliver, E., Smalley, R., Arblaster, J., Holbrook, N., Duke, N., Pearce, K., Braganza, K., and Bindoff, N.: Climate drivers of the 2015 Gulf of Carpentaria mangrove dieback, Earth Systems and Climate Change Hub Technical Report No. 2, 2017.

Hayes, M. A., Jesse, A., Welti, N., Tabet, B., Lockington, D., and Lovelock, C. E.: Groundwater enhances above-ground growth in mangroves, J. Ecol., 107, 1120-1128, 2019.

Hughes, T. P., Kerry, J. T., Álvarez-Noriega, M., Álvarez-Romero, J. G., Anderson, K. D., Baird, A. H., Babcock, R. C., Beger, M., Bellwood, D. R., Berkelmans, R., Bridge, T. C., Butler, I. R., Byrne, M., Cantin, N. E., Comeau, S., Connolly, S. R., Cumming, G. S., Dalton, S. J., Diaz-Pulido, G., Eakin, C. M., Figueira, W. F., Gilmour, J. P., Harrison, H. B., Heron, S. F., Hoey, A. S., Hobbs, J. P. A., Hoogenboom, M. O., Kennedy, E. V., Kuo, C. Y., Lough, J. M., Lowe, R. J., Liu, G., McCulloch, M. T., Malcolm, H. A., McWilliam, M. J., Pandolfi, J. M., Pears, R. J., Pratchett, M. S., Schoepf, V., Simpson, T., Skirving, W. J., Sommer, B., Torda, G., Wachenfeld, D. R., Willis, B. L., and Wilson, S. K.: Global warming and recurrent mass bleaching of corals, Nature, 543, 373-377, 2017.

Imbert, D., Rousteau, A., and Scherrer, P.: Ecology of mangrove growth and recovery in the Lesser Antilles: state of knowledge and basis for restoration projects, Restor. Ecol., 8, 230-236, 2000.

Ishikawa, N. F., Chikaraishi, Y., Takano, Y., Sasaki, Y., Takizawa, Y., Tsuchiya, M., Tayasu, I., Nagata, T., and Ohkouchi, N.: A new analytical method for determination of the nitrogen isotopic composition of methionine: Its application to aquatic ecosystems with mixed resources, Limnol. Oceanogr.-Meth., 16, 607-620, 2018.

Jeffrey, L. C., Reithmaier, G., Sippo, J. Z., Johnston, S. G., Tait, D. R., Harada, Y., and Maher, D. T. : Are methane emissions from mangrove stems a cryptic carbon loss pathway? Insights from a catastrophic forest mortality, New Phytol., 224, 146-154, 2019.

Kaplan, I. and Rittenberg, S.: Microbiological fractionation of sulphur isotopes, Microbiology, 34, 195-212, 1964.

Kelleway, J. J., Mazumder, D., Baldock, J. A., and Saintilan, N.: Carbon isotope fractionation in the mangrove Avicennia marina has implications for food web and blue carbon research, Estuar. Coast. Shelf S., 205, 68-74, 2018.
Krauss, K. W. and Osland, M. J.: Tropical cyclones and the organization of mangrove forests: a review, Ann. Bot., 125, 213-234, 2019.

Larsen, T., Taylor, D. L., Leigh, M. B., and O'Brien, D. M.: Stable isotope fingerprinting: a novel method for identifying plant, fungal, or bacterial origins of amino acids, Ecology, 90, 3526-3535, 2009.

Larsen, T., Wooller, M. J., Fogel, M. L., and O’Brien, D. M.: Can amino acid carbon isotope ratios distinguish primary producers in a mangrove ecosystem?, Rapid Commun. Mass Spectrom., 26, 1541-1548, 2012.

Larsen, T., Ventura, M., Andersen, N., O’Brien, D. M., Piatkowski, U., and McCarthy, M. D.: Tracing Carbon Sources through Aquatic and Terrestrial Food Webs Using Amino Acid Stable Isotope Fingerprinting, PLoS ONE, 8, e73441, https://doi.org/10.1371/journal.pone.0073441, 2013.

Larsen, T., Bach, L. T., Salvatteci, R., Wang, Y. V., Andersen, N., Ventura, M., and McCarthy, M. D.: Assessing the potential of amino acid ${ }^{13} \mathrm{C}$ patterns as a carbon source tracer in marine sediments: effects of algal growth conditions and sedimentary diagenesis, Biogeosciences, 12, 4979-4992, https://doi.org/10.5194/bg-12-4979-2015, 2015.

Lee, S. Y.: Carbon dynamics of Deep Bay, eastern Pearl River estuary, China. II: Trophic relationship based on carbon-and nitrogen-stable isotopes, Mar. Ecol.-Prog. Ser., 205, 1-10, 2000.

Lin, G. and Sternberg, L.: Differences in morphology, carbon isotope ratios, and photosynthesis between scrub and fringe mangroves in Florida, USA, Aquat. Bot., 42, 303-313, 1992a.

Lin, G. and Sternberg, L.: Effect of growth form, salinity, nutrient and sulfide on photosynthesis, carbon isotope discrimination and growth of red mangrove (Rhizophora mangle L.), Funct. Plant Biol., 19, 509-517, 1992b.

Lovelock, C. E., Feller, I. C., Reef, R., Hickey, S., and Ball, M. C.: Mangrove dieback during fluctuating sea levels, Sci. Rep.-UK, 7, 1680, https://doi.org/10.1038/s41598-017-01927-6, 2017.

Maher, D. T., Santos, I. R., Golsby-Smith, L., Gleeson, J., and Eyre, B. D.: Groundwater-derived dissolved inorganic and organic carbon exports from a mangrove tidal creek: The missing mangrove carbon sink?, Limnol. Oceanogr., 58, 475-488, $2013 \mathrm{a}$.

Maher, D. T., Santos, I. R., Leuven, J. R. F. W., Oakes, J. M., Erler, D. V., Carvalho, M. C., and Eyre, B. D.: Novel Use of Cavity Ring-down Spectroscopy to Investigate Aquatic Carbon Cycling from Microbial to Ecosystem Scales, Environ. Sci. Technol., 47, 12938-12945, 2013b.

Maher, D. T., Call, M., Santos, I. R., and Sanders, C. J.: Beyond burial: lateral exchange is a significant atmospheric carbon sink in mangrove forests, Biology Letters, 14, 20180200, 2018.

Mbense, S., Rajkaran, A., Bolosha, U., and Adams, J.: Rapid colonization of degraded mangrove habitat by succulent salt marsh, S. Afr. J. Bot., 107, 129-136, 2016.

McCutchan, J. H., Lewis Jr., W. M., Kendall, C., and McGrath, C. C.: Variation in trophic shift for stable isotope ratios of carbon, nitrogen, and sulfur, Oikos, 102, 378-390, 2003.

McKee, K. L., Feller, I. C., Popp, M., and Wanek, W.: Mangrove isotopic $\left(\delta^{15} \mathrm{~N}\right.$ and $\left.\delta^{13} \mathrm{C}\right)$ fractionation across a nitrogen vs. phosphorus limitation gradient, Ecology, 83, 1065-1075, 2002.

McKee, K. L., Rooth, J. E., and Feller, I. C.: Mangrove recruitment after forest disturbance is facilitated by herbaceous species in the Caribbean, Ecol. Appl., 17, 1678-1693, 2007. 
McMahon, K. W., Fogel, M. L., Elsdon, T. S., and Thorrold, S. R.: Carbon isotope fractionation of amino acids in fish muscle reflects biosynthesis and isotopic routing from dietary protein, J. Anim. Ecol., 79, 1132-1141, 2010.

Milbrandt, E., Greenawalt-Boswell, J., Sokoloff, P., and Bortone, S.: Impact and response of Southwest Florida mangroves to the 2004 hurricane season, Estuar. Coast., 29, 979-984, 2006.

Ohkouchi, N., Chikaraishi, Y., Close, H. G., Fry, B., Larsen, T., Madigan, D. J., McCarthy, M. D., McMahon, K. W., Nagata, T., Naito, Y. I., Ogawa, N. O., Popp, B. N., Steffan, S., Takano, Y., Tayasu, I., Wyatt, A. S. J., Yamaguchi, Y. T., and Yokoyama, Y.: Advances in the application of amino acid nitrogen isotopic analysis in ecological and biogeochemical studies, Org. Geochem., 113, 150-174, 2017.

Okada, N. and Sasaki, A.: Characteristics of Sulfur Uptake by Mangroves: an Isotopic Study, Tropics, 4, 201-210, 1995.

Okada, N. and Sasaki, A.: Sulfur isotopic composition of mangroves, Isot. Environ. Healt. S., 34, 61-65, 1998.

Otero, X. L., Méndez, A., Nóbrega, G. N., Ferreira, T. O., SantisoTaboada, M. J., Meléndez, W., and Macías, F.: High fragility of the soil organic $\mathrm{C}$ pools in mangrove forests, Mar. Pollut. Bull., 119, 460-464, 2017.

Rashid, S., Biswas, S. R., Böcker, R., and Kruse, M.: Mangrove community recovery potential after catastrophic disturbances in Bangladesh, Forest Ecol. Manage., 257, 923-930, 2009.

Raven, M. R., Fike, D. A., Gomes, M. L., and Webb, S. M.: Chemical and isotopic evidence for organic matter sulfurization in redox gradients around mangrove roots, Front. Earth Sci., 7, 98, https://doi.org/10.3389/feart.2019.00098, 2019.

Reef, R., Feller, I. C., and Lovelock, C. E.: Nutrition of mangroves, Tree Physiol., 30, 1148-1160, 2010.

Santini, N. S., Reef, R., Lockington, D. A., and Lovelock, C. E.: The use of fresh and saline water sources by the mangrove Avicennia marina, Hydrobiologia, 745, 59-68, 2015.

Sasmito, S. D., Kuzyakov, Y., Lubis, A. A., Murdiyarso, D., Hutley, L. B., Bachri, S., Friess, D. A., Martius, C., and Borchard, N.: Organic carbon burial and sources in soils of coastal mudflat and mangrove ecosystems, CATENA, 187, 104414, https://doi.org/10.1016/j.catena.2019.104414, 2020.

Sherman, R. E., Fahey, T. J., and Martinez, P.: Hurricane Impacts on a Mangrove Forest in the Dominican Republic: Damage Patterns and Early Recovery 1, Biotropica, 33, 393-408, 2001.

Silliman, B. R., van de Koppel, J., Bertness, M. D., Stanton, L. E., and Mendelssohn, I. A.: Drought, Snails, and Large-Scale DieOff of Southern U.S. Salt Marshes, Science, 310, 1803-1806, 2005.

Sippo, J. Z., Lovelock, C. E., Santos, I. R., Sanders, C. J., and Maher, D. T.: Mangrove mortality in a changing climate: An overview, Estuar. Coast. Shelf S., 215, 241-249, 2018.

Sippo, J. Z., Maher, D. T., Schulz, K. G., Sanders, C. J., McMahon, A., Tucker, J., and Santos, I. R.: Carbon outwelling across the shelf following a massive mangrove dieback in Australia: Insights from radium isotopes, Geochim. Cosmochim. Ac., 253, 142-158, 2019.

Sippo, J. Z., Santos, I. R., Sanders, C. J., Gadd, P., Hua, Q., Lovelock, C. E., Santini, N. S., Johnston, S. G., Harada, Y., Reithmeir, G., and Maher, D. T.: Reconstructing extreme climatic and geochemical conditions during the largest natural mangrove dieback on record, Biogeosciences, 17, 4707-4726, https://doi.org/10.5194/bg-17-4707-2020, 2020a.

Sippo, J. Z., Sanders, C. J., Santos, I. R., Jeffrey, L. C., Call, M., Harada, Y., Maguire, K., Brown, D., Conrad, S. R., and Maher, D. T.: Coastal carbon cycle changes following mangrove loss, Limnol. Oceanogr., https://doi.org/10.1002/lno.11476, online first, 2020b.

Sjöling, S., Mohammed, S. M., Lyimo, T. J., and Kyaruzi, J. J.: Benthic bacterial diversity and nutrient processes in mangroves: impact of deforestation, Estuar. Coast. Shelf S., 63, 397-406, 2005.

Smallwood, B. J., Wooller, M. J., Jacobson, M. E., and Fogel, M. L.: Isotopic and molecular distributions of biochemicals from fresh and buried Rhizophora mangle leaves, Geochem. T., 4, 38-46, 2003.

Smith, T. J., Robblee, M. B., Wanless, H. R., and Doyle, T. W.: Mangroves, hurricanes, and lightning strikes: assessment of Hurricane Andrew suggests an interaction across two differing scales of disturbance, BioScience, 44, 256-262, 1994.

Stott, P.: How climate change affects extreme weather events, Science, 352, 1517-1518, 2016.

Sweetman, A. K., Middelburg, J. J., Berle, A. M., Bernardino, A. F., Schander, C., Demopoulos, A. W. J., and Smith, C. R.: Impacts of exotic mangrove forests and mangrove deforestation on carbon remineralization and ecosystem functioning in marine sediments, Biogeosciences, 7, 2129-2145, https://doi.org/10.5194/bg-7-2129-2010, 2010.

Thomson, J. A., Burkholder, D. A., Heithaus, M. R., Fourqurean, J. W., Fraser, M. W., Statton, J., and Kendrick, G. A.: Extreme temperatures, foundation species, and abrupt ecosystem change: an example from an iconic seagrass ecosystem, Glob. Change Biol., 21, 1463-1474, 2015.

Tomlinson, P. B.: The botany of mangroves, Cambridge University Press, New York, NY, USA, 2016.

Trust, B. and Fry, B.: Stable sulphur isotopes in plants: a review, Plant Cell Environ., 15, 1105-1110, 1992.

Vander Zanden, M. J. and Rasmussen, J. B.: Variation in $\delta^{15} \mathrm{~N}$ and $\delta^{13} \mathrm{C}$ trophic fractionation: Implications for aquatic food web studies, Limnol. Oceanogr., 46, 2061-2066, 2001.

Walsh, R. G., He, S., and Yarnes, C. T.: Compound-specific $\delta^{13} \mathrm{C}$ and $\delta^{15} \mathrm{~N}$ analysis of amino acids: a rapid, chloroformate-based method for ecological studies, Rapid Commun. Mass Sp., 28, 96-108, https://doi.org/10.1002/rcm.6761, 2014.

Wernberg, T., Bennett, S., Babcock, R. C., de Bettignies, T., Cure, K., Depczynski, M., Dufois, F., Fromont, J., Fulton, C. J., Hovey, R. K., Harvey, E. S., Holmes, T. H., Kendrick, G. A., Radford, B., Santana-Garcon, J., Saunders, B. J., Smale, D. A., Thomsen, M. S., Tuckett, C. A., Tuya, F., Vanderklift, M. A., and Wilson, S.: Climate-driven regime shift of a temperate marine ecosystem, Science, 353, 169-172, 2016.

Werth, M., Mehltreter, K., Briones, O., and Kazda, M.: Stable carbon and nitrogen isotope compositions change with leaf age in two mangrove ferns, Flora-Morphology, Distribution, Funct. Ecol. Plants, 210, 80-86, 2015. 